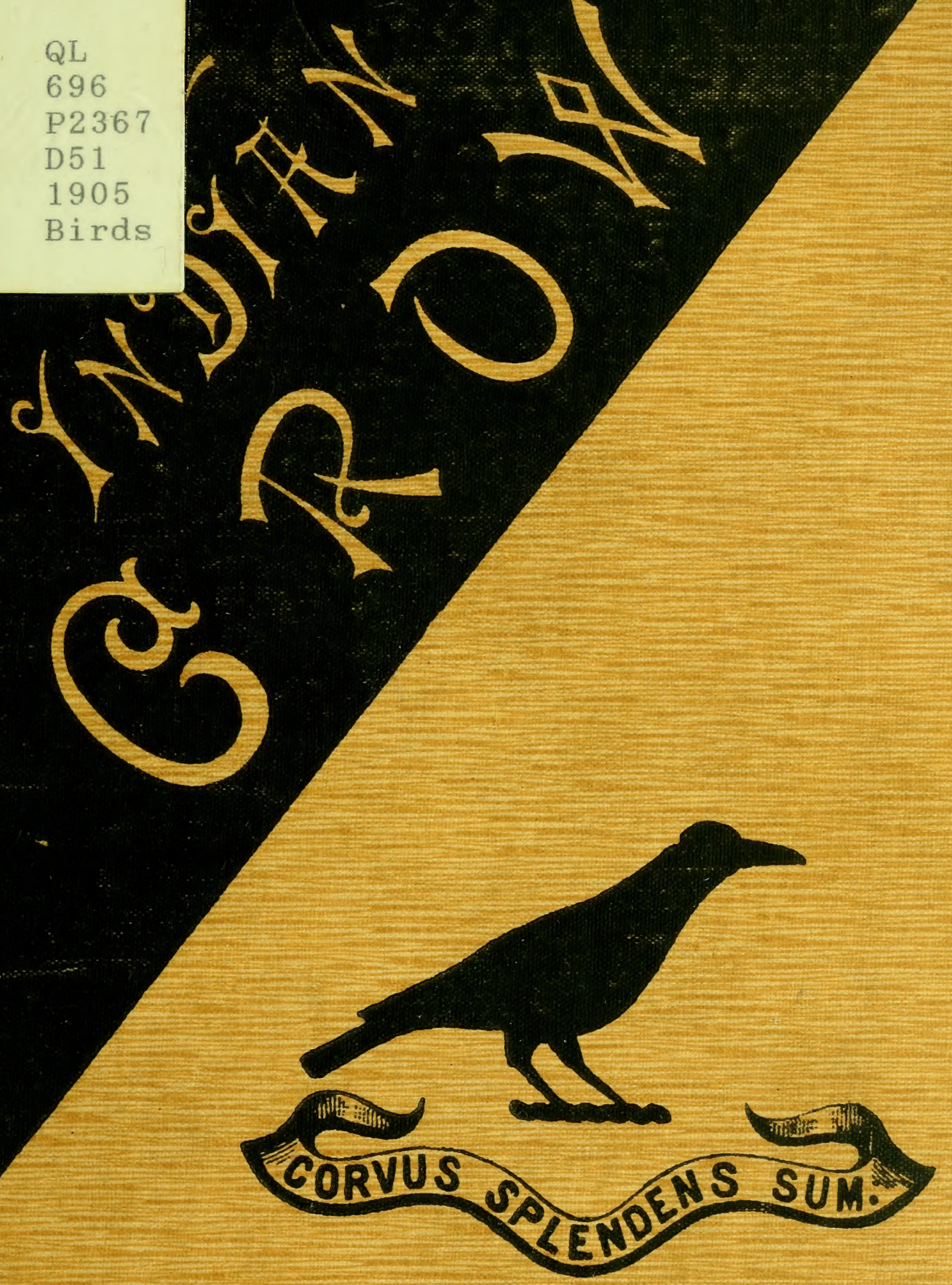



Division of Birds 



\section{THE INDIAN CROW:}

\section{HIS B00K}

BY

DOUGLAS DEWAR, B.A. (Cantab.), F.z.s., AUthor OF "Animals of No Importance."

Madras:

HIGGINBOTHAM \& Co.

1905. 


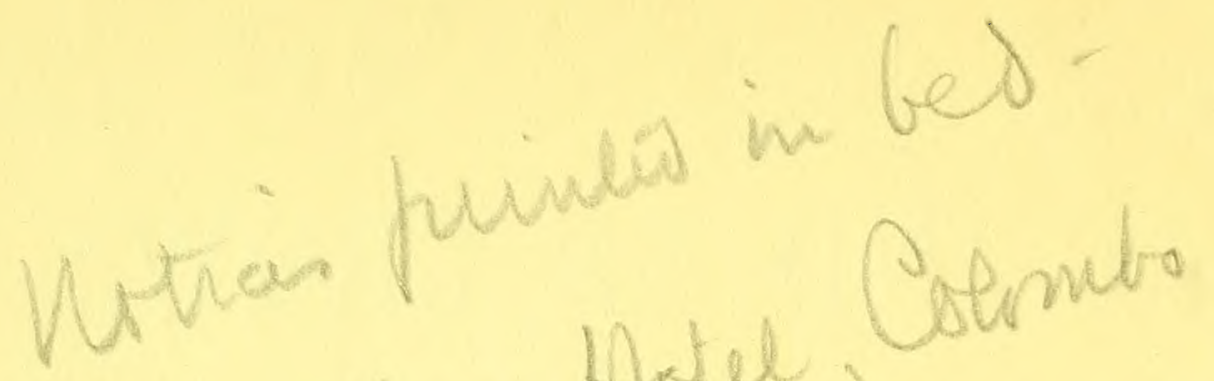

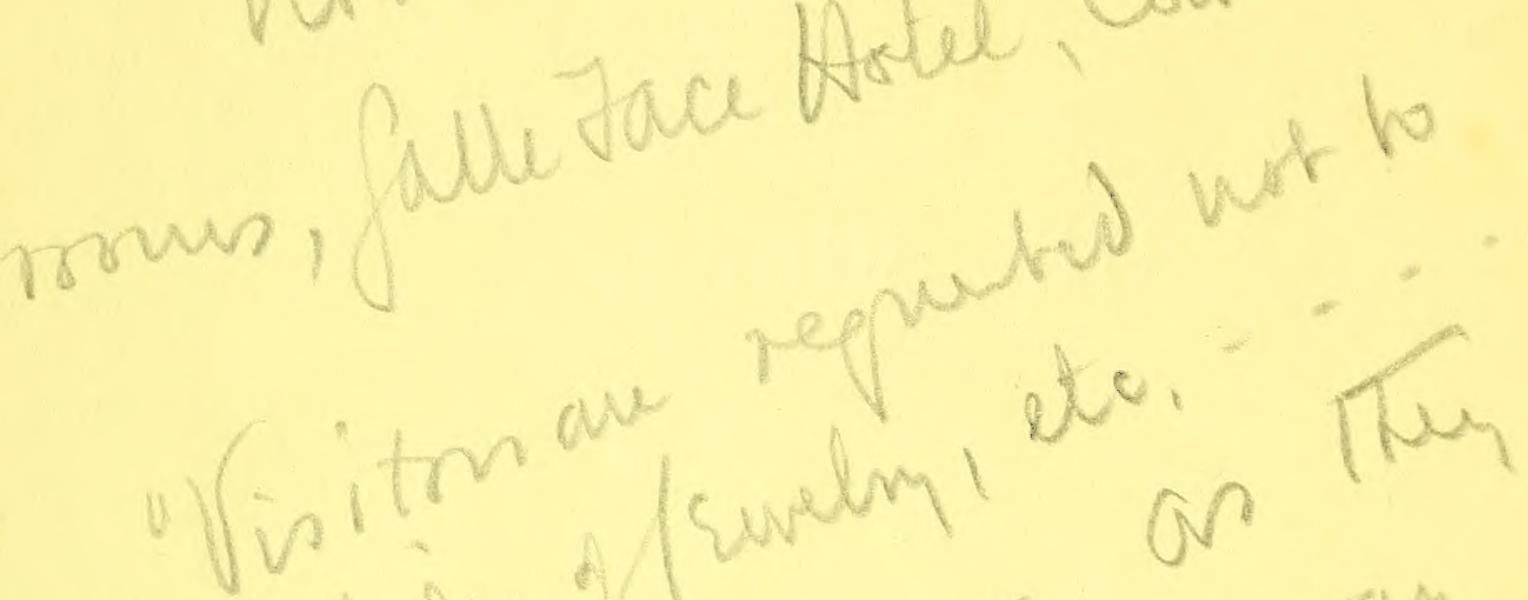

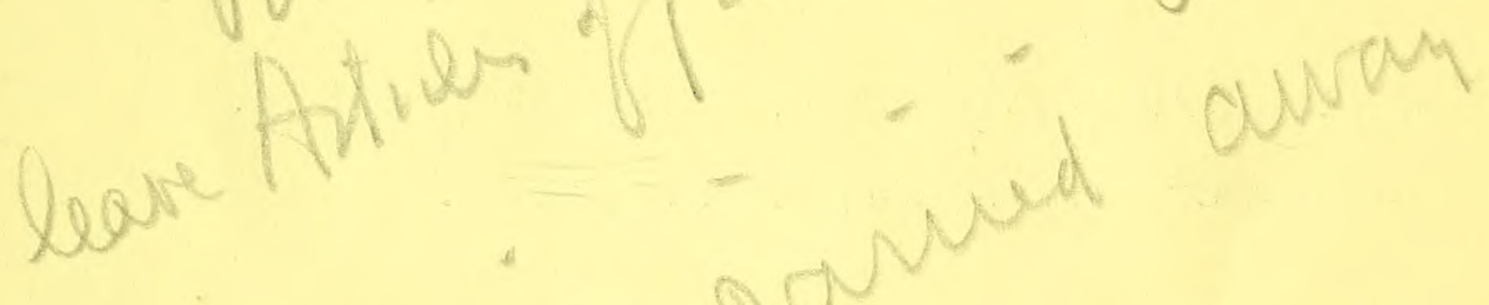

we<smiles>C1=CCCC=1</smiles>

e a jur

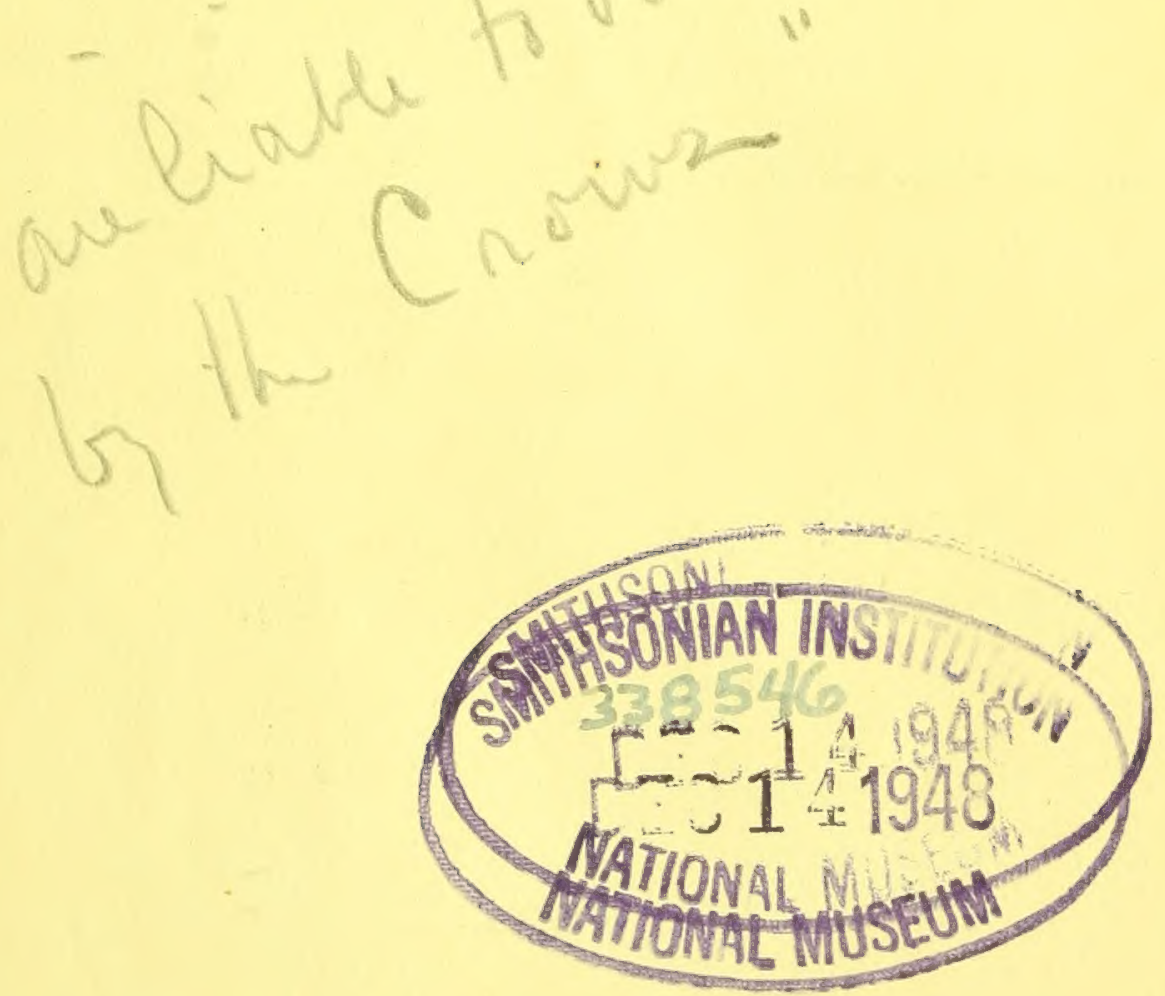




\section{PREFACE.}

Of prefaces there are two species - the preface apologetic and the preface defiant. The former displays two well-marked varieties-the only-at-the-instigation-of-friends preface, and the this-book-is-full-of-faults-and-no-oneis - more-conscious - of - them - than-the - author preface.

It is obviously not open to me to adopt the former of these varieties, for, like the worthy George Washington, I cannot tell a lie, especially when there is no chance of its obtaining credence.

Nor am I going to fall back upon the second variety of the preface apologetic. It seems to me that it is intended only for hypocrites and simpletons. 
If you are trying to sell a horse, you don't say to the prospective purchaser " I'm afraid he is rather a crock. He fell down three times yesterday You will notice that his knees are cut, that he is a bit dicky about the hind quarters, and that he is touched in the wind. $\mathrm{He}$ is a trifle free with his hind legs, and jibs like fury, but I have had his teeth filed down to improve his appearance." If you are honest, you say as little as possible about the horse, you merely whisper to yourself caveat emptor.

If honesty is not your strong point, you-er, well, you don't dwell upon the horse's faults; to do so would be unkind.

I am honest, so I say as little as possible about the contents of this book. Thus we have eliminated all but the preface defiant. So here goes. I offer no apology for producing this book. Far from it. I apologise for the 
previous neglect of the splendid bird by those naturalists who have already served their time in the Gorgeous East.

Is it fitting, nay, is it decent, that the Crow who forms part and parcel of human existence in the Land of Regrets, should have no book he can call his own, no scroll upon which his doughty deeds are writ large?

Horses-noble creatures, dogs-dear things, cats-obnoxious quadrupeds, pigeons-selfsatisfied birds, fowls-estimable beings, and even whales-unwieldly monsters, have books devoted exciusively to them.

Much more then should the Indian crow have his book.-Q.E.D.

Lovers of the crow will doubtless read and cherish this booklet. Those who love not the "treble-dated" bird will find in this brochure a most convenient missile to hurl at the offend- 
ing bird. Those who are indifferent to the crow-but, stay, do such exist? I trow not. They are mere figments of the brain, shadowy forms, which have no terror for even the timid writer.

Gentle reader, is it necessary for me to say that this wordy effusion has led, step by step, line upon line, to the irresistible conclusion that no one can afford to be without this little book?

Madras, April 1st, 1905. 
A considerable portion of this book has already appeared in print.

Chapters I and II made their rêbut in The Morning Post (Delhi). Chapter III made its bow in a slightly different form in The Mudras Mail. Certain incidents in the remaining chapters are reproduced almost verbatim from an article which appeared in Longman's Magazine.

It is owing to the kindness of the editors of the above-named publications that these chapters on the Indian crow have assumed book form. 
"In all respects, physiological, morphological and ornithological, the crow may be placed at the head, not only of its own real series (birds of the crow form), but also as the unchallenged chief of the whole of the carinatae."-Parker. 



\section{CONTENTS.}

CHAPTER I.

PAGE

His Chits

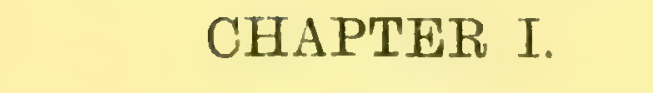

CHAPTER II.

His Methods of Obtaining a Livelihood $\quad$.. 9

CHAPTER III.

His Domestic Affairs $\quad \ldots \quad$.. $\quad \ldots \quad 24$

CHAPTER IV.

His Habits

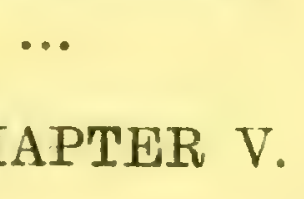

His Amusements

CHAPTER V.

.. 35

... 49

CHAPTER VI.

His Foes 



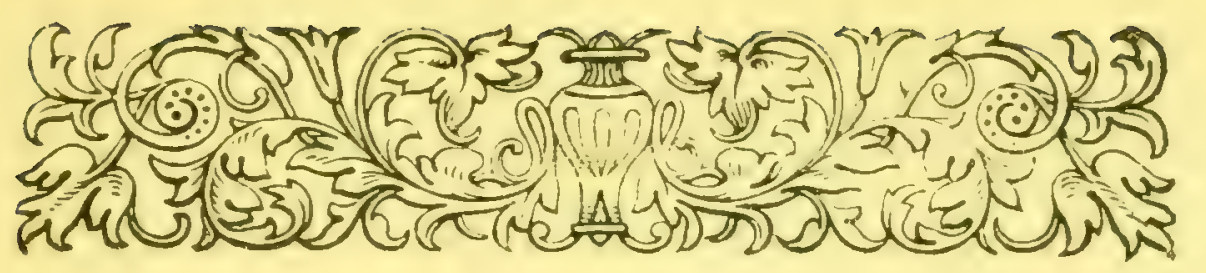

\section{CHAPTER I.}

\section{HIS CHITS.}

A NAl'IVE; without chits is like a ship without a A heln. Corvus splendens, being an oriental bird and accustomed to Indian ways, would be most unhappy were I to introduce him without first showing his testimonials, indifferent although many of them be. In this country, however, as everyone who has been a month in it has discovered, so long as a man has a good supply of chits their subject-matter is of no importance ; it is also a matter of supreme indifference whether the contents of the aforesaid chits refer to the holder, his great grandfather, or any other person. So long as a servant is able to flaunt a package of greasy testimonials before his future master, this latter has no right to demand more.

Of chits the crow has a multitude. These are all his very own: they refer to him and not to any other 
bird. What is more, they bear many illustrious signatures, and they are. one and all, written as the result of much reflection, and not, as is the case with most of the Indian servant's rhits, scribbled on the platform as the train is coming into the station, or composed by a worn-out individual squatting on at packing case in a bungalow rendered a 'Tower of Babel by a number of coolies doing a little furniture removing. Another reason why the chits of the crow contain real opinions is that the bird is without the pale of the Indian Penal Code. He is doli incapax This means that he may steal your property and you cannot prosecute him. But, on the other hand, you may abuse him to your hear't's content and he cannot bring a defamation case against you. Nay more, you may shoot him without fear of a police-officer appearing on the premises next day. If you kill it crow the worst that can happen is that all the rest of the corvidate of the neighbourhoud will come and abuse you, and possibly one or two superstitious servants may desert during the night.

Some of the crow's testimonials date from very early times. 'Thus the sage Pratyasataka said, far' back in the dim vista of time, "nothing can improve 
a crow." That worthy philosopher in tended to imply. that the crow was so depraved as to be beyond redemption. The sagacious bird, however, has been sharp enough to notice the ambiguity of the utterance, which might have emanated from the Delphic Oracle. He takes advantage of this to interpret the saying as meaning that the crow is perfect, hence no improvement is possible, that he has attained the highest pinnacle of righteousness and can therefore mount no higher. Fortunately for the crow he is able to adduce some evidence in support of his contention. for the Hindu law-giver. Manu, once said "a good wife should be like a crow." The bird treasures up this saying, it is to him as the apple of his eye.

There is, however, nothing ambiguous about the testimonials which the British poets have given the crow. In this case the bards have made no bones about calling a spade a spade. A few extracts from their chits follow. There is. I submit, no beating about the bush in them. "The ignoble crow," "The dastard crow," "Turking villain crow," "The perditious crow," "The treble-dated crow." If you tell a crow that these hard names should make him hide his diminished head, he puts that organ on one 
side, winks the left eye, and salys with a lond caw " those refer to my English cousins, and not to me. British crows are indeed naughty creatures, but even they have one good chit, for did not the poet Shelley call them 'prophetic birds,' and it is for this reason that they have no honour in their own country."

The naturalist, being a student of animal character, probes below the surface; he carefully analyses the mind of the crow, and for this reason his testimonials usually attain some length. I will now proceed to give what native booksellers call "Selected Extracts."

The following contains the quintessence of Phil. Robinson's chit: "Crows are indubitably the connecting link between devils, Class 3 , inventors of all mischief, Prince Belial at their head; and Class 4, malicious devils. under Prince Asmodeus."

Eha writes: "I have never been able to discover any shred of grace about an Indian crotr. And what aggravates this state of things is the imposture of its outward appearance. It affects to be respectable and entirely ignores public opinion, dresses like a gentleman, carries itself jauntily, and examines everything with one eye in a way which will certainly bring on an eye-glass in time if there is a scrap of 
truth in the development theory. But for this defiance of shame one might feel disposed to make allowances for the unhappy influences of its life ; for, in truth, it would be strange if a crow developed an amiable character. Fven a consistent career of crime must be less demoralizing than the aimless vagabondage by which it maintains itself."

More mature comsideration does not seem to have raised Fhat's estimate of the corvine character, for in "The Common Birds of Bombay" that writer gives the bird the following chit: "I have never felt a qualu of conscience ahout taking a crow's life. It is not their depredations. nor their impudence, nor their rowdy noises. I could endure all these. What I cannot forgive is the constant and ruthless massacre of imnocents that goes on where crows are allowed to have their own way. 'They watch every little bird to find out if it have a nest, they count the days till the first young sparrow flutter's out on its untried wings, they pounce upon it and carry it to the nearest tree and hold it under one foot and pick it to pieces, absolutely callous to the shrieks of the parents as they

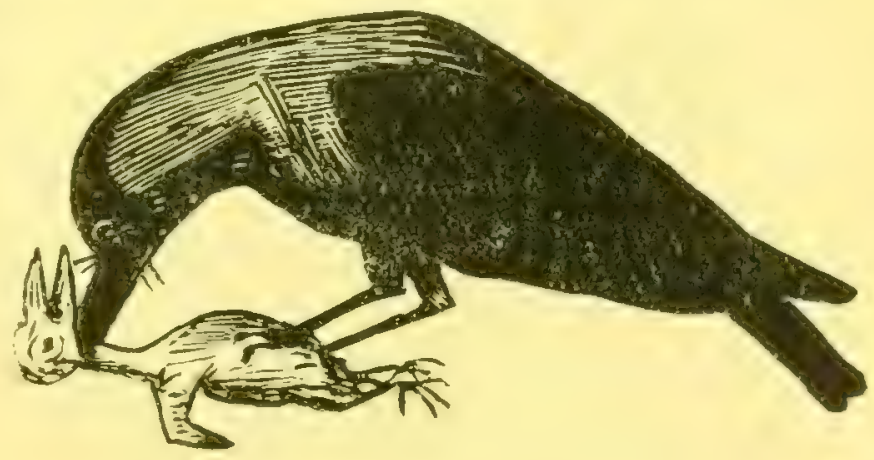


Hutter round, distracted but helpless. For this I shoot the crow without remorse."

Lockwood Kipling dwells upon another aspect of the crow's character. According to him, these birds are " thieves, outcast scavengers, deceitful, and, above all other creatures that hoard and hide. clever in concealing things."

Jerdon, too, is very severe on the bird. He would take away its fine name. exchange it for some term of opprobrium. for he thinks that to describe the Indian crow as corvus splendens "tends to bring into ridicule, among the unscientific, the system of nomenclature." Hodgson went one better. He actually did call the bird Corvus impudicus, but he could not induce other ornithologists to follow hin, so the grey-necked crow still remains Corvus splendens.

Colonel Cunningham stigmatises the crow as "an irrepressible street gamin, ready for any fray, opportunity for theft, or occasion for annoying and tormenting his neighbours. As a rule, he is quite ready to say, with Madame de Longueville when exiled from Paris and condemned to stay with her husband in Normandy, 'Je n'aime pas les plaisir's innocents." ", 
Mr. F. Finn, however, takes a more favourable view of the bird. According to him "the crow is a bird of many social virtues; he will certainly rescue a friend in distress if he can, for his evident and loudly expressed indignation when one handles a dead or living comrade of his makes it plain that a less powerful enemy than man would probably be seriously attacked. Also he is a good husband, feeding his wife assiduously, and letting her pull their common booty away from him; and a tender parent, much attached to his abominable offspring, in defence of which he will attack human beings at times." I agree with Mr. Finn, and have given the crow upon more than one occasion an excellent rhit. I once took up a whole column of the valuable space of a newspaper in white-washing the bird. I have gone further. I have dedicated a book to him. For this I have been taken to task by a naturalist who loveth not the crow and who chided me for " most wrongly and perversely" affecting that "vilest of all vermin," the crow.

All I can say in reply is that I know of no bird or beast so amusing to watch as the crow. If any man can witness the doings of an Indian crow for ten 
minutes without smiling, that man should at once apply for six months' leave on medical certificate. To me India without crows would be as insipid as lamb without mint sauce. I grant that the crow is a wicked bird, but his wickedness is of the attractive picturesque type.

Those who like not to read of villainies had better studiously avoid these chapters. To such I would recommend a book called "Sianford and Merton."

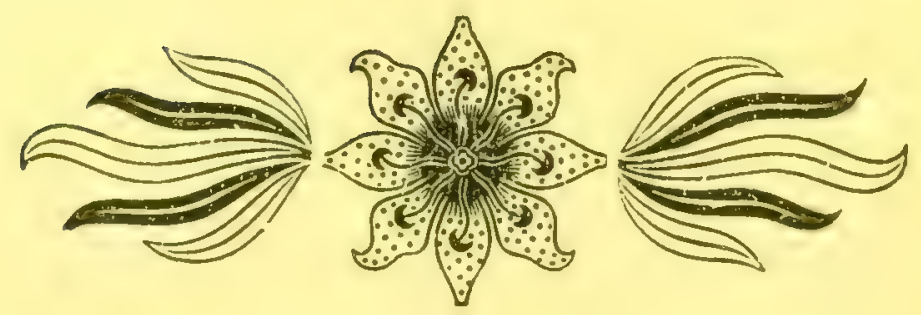




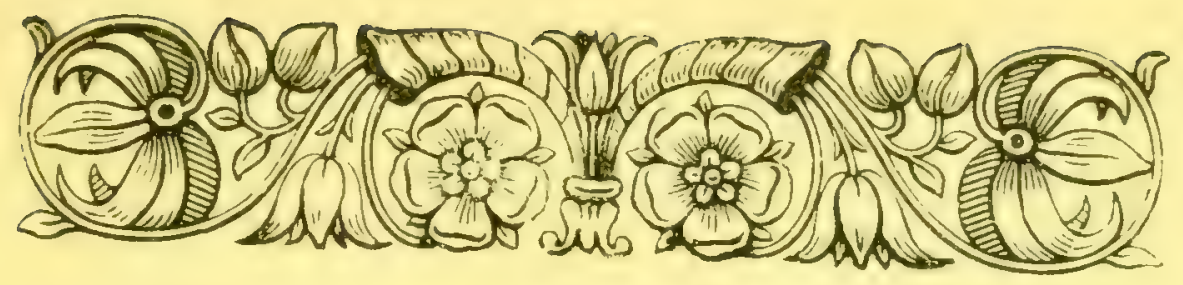

\section{CHAPTER II.}

\section{HIS METHODS OF OBTAINING A LIVELIHOOD.}

CROWs are the Yankees of the bird world. They can adapt themselves to any situation or circumstance. They are not tied down to one special lind of food, nor are their actions hampered by the Ten Con:mandments. They eat anything and everything. They will refuse nothing capable of being digested by an ostrich, and I imagine that they devour a great many things which even a drel-bungalow khansecmule would hardly have the conscience to call digestible.

The ways in which crows ohtain their food make a most interesting study.

The vultures are not allowed to devour a carcass in peace. there aro always somer coposs who insist on sharing the zimesome repast. The corvilas are nseful scavengers in their way for they will eat any refuse. As the municipal sweepers fill the dust-bins in Madras they are usually watched by a number of interester crows who boldly sit on the edge of the hin and 
too clever to perch on the basket, for, had he done so). he would have betrayed his presence; he quietly flew along at the woman's own pace and served himself until he had eaten all he required. If there were butcher's and fish-nonger's boys in India these would have to give up their practice of carrying meat and fish in trays on the head, for provisions carried in this way would never arrive at their destination in this country. A collection of crows is invariably to be seen ontside the sahil's kitchen at the usual time when the cook, regardless of the principles of sanitation, casts forth into the compound the remains of the last meal.

Crows inpudently invade the bungalow and steal whatever they can seize with their great beaks. They appear to have a use for everything portablespoons, postage stamps and babies' socks seem to have a special attraction for the birds.

Having heard wonderful stories of the depredations of the crows in the General Hospital at Madras, I wrote to Captain D. C. Kemp, one of the Resident Surgeons, in order to obtain authentic information. I received the following letter in reply:-

"The crows have been such a nuisance in this hospital that we have had to have wire cover's (like 
meat cover's. but with larger netting) made to protect the small tables beside each patient's bed.

On these side tables each patient has his or her daily portion of food, placed for his or her convenience. The crows watch out for the old and the infirm, or for those who have their limbs in splints or are otherwise obviously not able to move: one or more crows will victimise these unfortunate patients with the greatest ingennity, and will certainly rob them of their food if there is no cover to protect the plates.

There used to be a dear old feeble lady in hospital who was obliged to wear a green shade to her eyes. This lady had almost to fight for her daily meals. Two crows would get down beside her, one on each side, and fairly worry the old lady's life with feint and attack before she could safely get her rations stored in ventri.

Many a time do these crows swoop down on letters and papers. In one case a Eurasian patient had just put down a letter he had received from some "loved one' and a crow had just carried it off and was tearing it up in great style, to the chorus of the patient's 
swear words, when the nurse entered the ward. Even then the bird declined to take any notice of flying: mops and dusters.

We have a special staff of 'crow-boys' (chokras of about 8 to 14 years of age) whose raison d'etre is the alarming away of these pernicious corvi.

Needless to say the staff is futile for the purpose. The boys are provided with string bows, with which to aim stones at Mr. Corvus.

I do not believe that anything short of gumpowder fringed with No. 4 or No. 8 will exercise the slightest influence over these companions of the poor,-who are always with us."

Crows seem to be particularly partial to hospitals. 'The author of The Civilian in Lower Bengal relates the following anecdote.

"On one occasion as I was passing the principal police station (at Dacca) I saw a crowd gathered round, and went to ascertain the cause. There I found a beautiful Cashmeri woman lying on the floor with her robe almost off, and positively weltering in blood. It turned out that her husband had 
cut off her nose-a little way Indian husbands have." The author ordered a search to be made for the nose and directed it to be fitted on again if found. The nose was found. The writer continues "I went away as I had plenty to do; but in the evening I called again at the hospital to enquire after the success of the operation; for, over and above my curiosity in the matter, I felt that, if successful, it would have some weight in overcoming the native prejudices against surgery after the European fashion.

The Sub-Assistant Surgeon cane out to me with rather a blank face. 'A calamity has happened' he said, "the mehtar' (the servant who does dirty work) was instructed to wash the nose in a basin of clean water" he left it in the basin for a moment and while his back was turned a crow came in and flew off with it.' ",

Often have I awoken in the morning to find that the crows have wrought sad havoc with my rhote hazin. The toast has vanished, the sugar has sadly diminished in quantity, a few greasy strealis on a plate mark the place once occupied by a respectable 
pat of butter: while nothing but the inconvenient shape of the jug has prevented the abstraction of the milk. I do not object very much to the crows taking my jam, but I think it distinctly bad form of them to afterwards clean their beaks on my table cloth.

Crows are guilty of yet more heinous offences than mere theft, they make no bones about highway robbery. A crow will robone of its own species or any other bird or beast. I used to possess a greyhound which suffered much at the hands
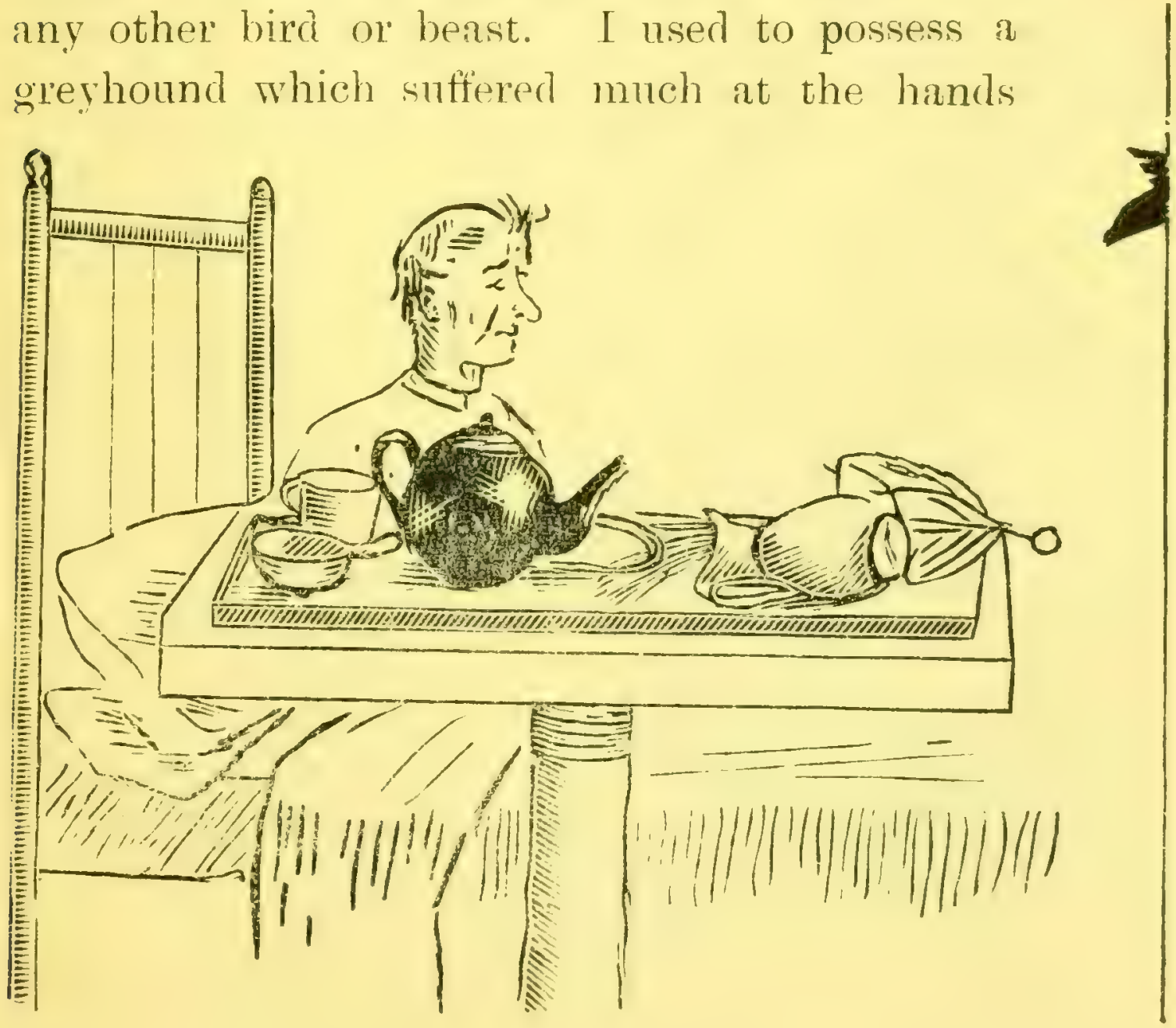
of these bold robbers: while she would be eating her food one or two crows would come up and, having wished her good evening, one of them would peck at her back or tail, and, as she turned her head to give the impudent bird a grid $p^{\prime \prime}$ yno, the other crows would snatch pieces of food from the dish. Upon one occasion the crows attacked her in such numbers that she was driven from her food and forced to look on, yelping helplessly, while the birds ate it up.

Is it to be wondered at that the crows flomish like the green bay tree? They are birds of prey. They like nothing so well as a tender young sparrow, fresh from the nest. Hence they make a special study of ornithology. Every crow is a first-class naturalist, and deserves to be made a member of the Zoological Society, but we do not receive our deserts in this world, and perhaps it is as well for the crows that we do not. If, however, their knowledge of

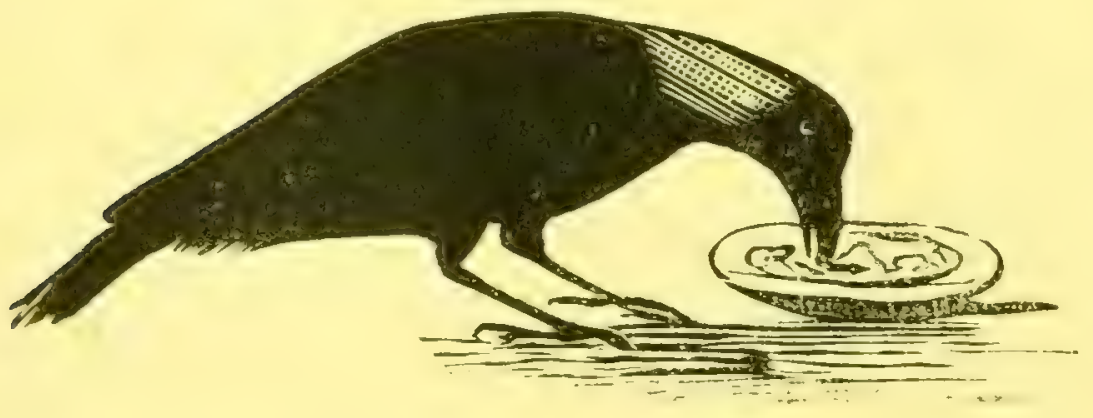
natural history brings them no honour they derive much profit there 
from, for they know the season of nesting for each species of bird and they raid every nest they discover. If they are so fortunate as to find young ones therein they promptly devour these. The crows recently ate up three young bulbuls which had been hatched out in a nest in the rhik-house in my compound. If the young birds have not yet arrived the black villains eat up the eggs. They regard this as an act of virtue since they save the hen bird the trouble of uselessly sitting on her eggs. Crows are always on the look out for eggs. I have seen one snatch up a pingpong ball that had fallen on the grass and then spend an unprofitable half hour in vain attempts to extract the yolk.

Crows are very fond of fruit; they are always among the first birds to attack a ripening mulberry or cherry tree. Nor is this the only depredation they commit in the garden. They will, out of sheer cussedness, uproot plants and pluck flowers. It is needless to say that they scrape up and eat newly-sown seeds. Crows will also steal things which are not ordinarily accounted nutritious. They are especially addicted to flying off with the slips of paper which the enthusiastic gardener places in cleft sticks pushed into 
the ground to mark the kind of seeds sown in that particular spot.

There is a certain old Colonel, whom I will not name, for he is not one to court fame, who stoutly declares that the crows, outof pure mischief, change the positions of these papers. He affirms that upon one occasion, when he put slips of paper to mark the position of some portulaccas and some phlozes. the crows actually had the effrontery to transpose those slips during the night. In justice to the crow and for the enlightenment of the reader I may say that the offenders belonged to the anthropoid species. Crows will steal these pieces of paper as they will steal and hide everything portable, but there is no credible evidence to show that they transpose the gardener's labels.

The crows always lieep an eye on the ripening crops. They are expert farmers. They know to an hour when each crop is sufficiently ripe for them to eat it. 'They turn their knowledge to account, for' the moment the crop is ready they betake themselves to the field and each bird selects a promising stalk and half hops, half flies on to the head, grasps it 
with his foot, and pulls it to the ground, where the grain is extracted with beak and claws.

Crows despise not the humble insect. For them a flight of "white ants" or locusts is quite a windiall. Upon such occasions they make merry among the winged swarm, catching the insects in the air and transferring them to the beak while on the wing.

In those parts of India where the grass is green throughout the year many of the crows habitually. turn themselves into starlings and wagtails; such may be seen on any mailun running along the ground after insects as mynas do. Funte de miend crows will eat the ticks which infest the skins of cattle. Nothing is commoner in India than the sight of one of these birds on the back of a cow or buffalo busily engaged in picking ticks out of the shin of the quadruped. The skill shown by the croms in performing the operation is wonderful. They could give points to any dentist. They never seem to hurt or harm the cattle as the jackdaws in England often do while attempting to render a similar service.

Two or three crows may usually be seen attending the ploughman as he follows the "lonely furrow." 
They do this, not from love of the cultivator, but to secure the worms and grubs exposed by the plough.

Every railway station in India has its colony of crows. which, like the hotel porters, meet each train and stalk up and down the platform with an eye for the main chance. I was once greatly amused by watching a party of these clever birds attacking a goods train laden with sacks of corn. The train had pulled up at a large junction, and, as is the way with Indian goods trains, seemed likely to wait there for many days. Meanwhile the crows were enjoying themselves. There were two or three of them upon each truck extracting with their powerful beaks the grain through the holes in the sacks. Whether the birds had made the holes themselves I am unable to say. I am inclined to think they had done so, for it is hardly likely that in this country, where "packing" forms a most important item on every invoice, the sacks would have been despatched full of holes.

Crows are very partial to tender young frogs, hence, after a heavy fall of rain, the versatile birds make for some flooded field and there hunt for crabs, frogs and insects. 
Jerdon states that "a few in the vicinity of the large river's or creeks, follow vessels and hunt with the gulls and the terns."

I have often seen them at the mouth of the River Cooum at Madras squabbling with the gulls over fish cast away by the fisherfolk.

Some of the crows that dwell by the sea pick up a living on the sands, and their modus operandi is worth noticing. There lives in the sand a little crab. He is built for sprinting, having long legs and a light slender body. Notwithstanding the fact that he, as do all his tribe, progresses
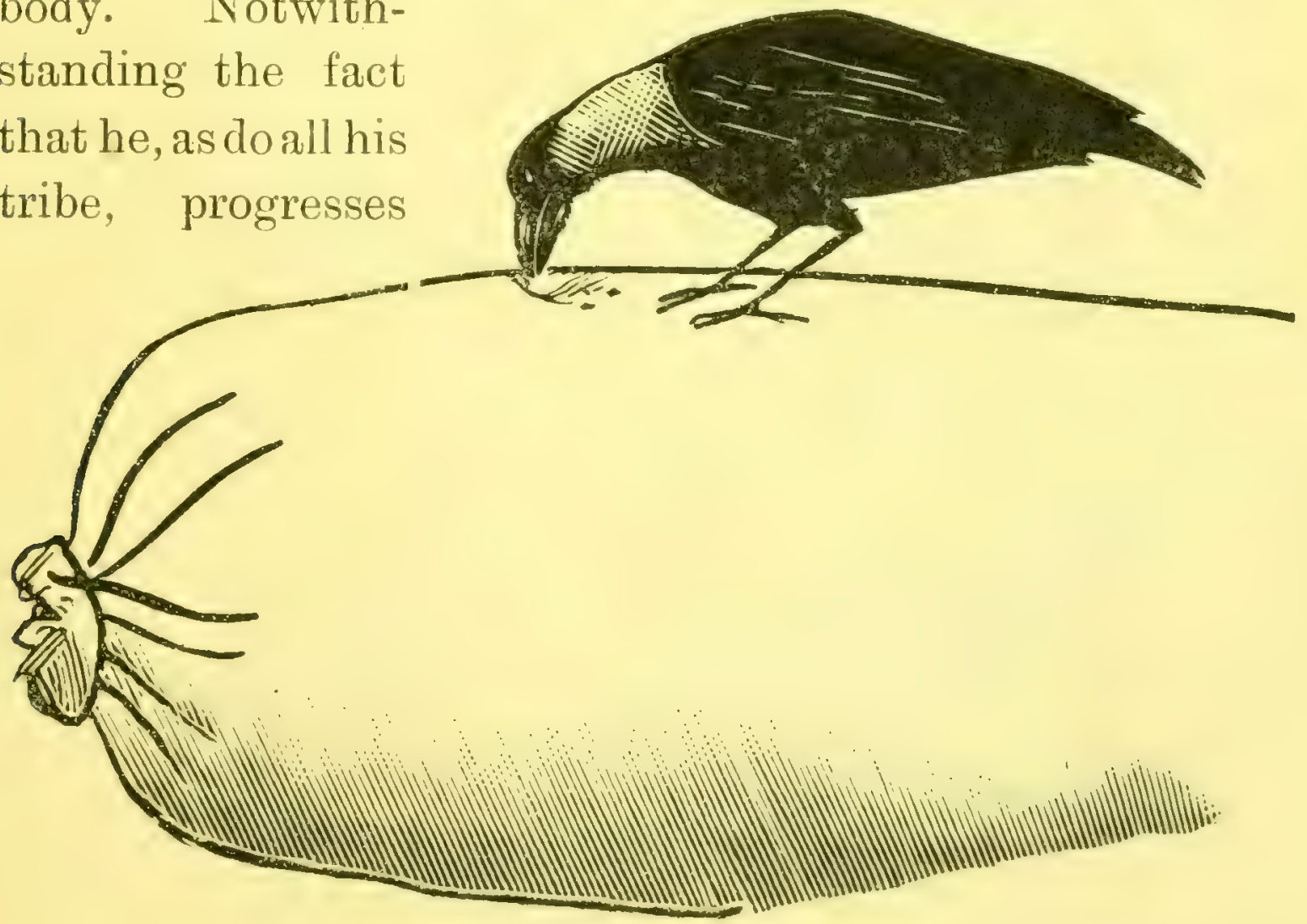
sideways, he is a swift runner. He appears to rely solely on his pace to secure his food. He makes for himself a burrow at the mouth of which he waits for his prey, which seems to consist of insects and small crustacea. When he espies one of these he makes a dash for it and seldom fails to catch it. If there appears to be no danger threatening he often ventures far from his hole. This is the chance for which a crow near by has been waiting, since the bird esteems this crab very highly as a table dish. He sees that his victim is far from home so makes a dash for him in hopes of grabbing him before he can regain the burrow. Whenever you see a crow running about on the sands as last as his legs can carry him, twisting, turning and doubling. you may know that the crow is chasing one of these crabs. More often than not the crustacean appears to escape, but if he be caught he is not kept long in suspense as to his fate, for within two seconds he is comfortably stowed away inside the crow.

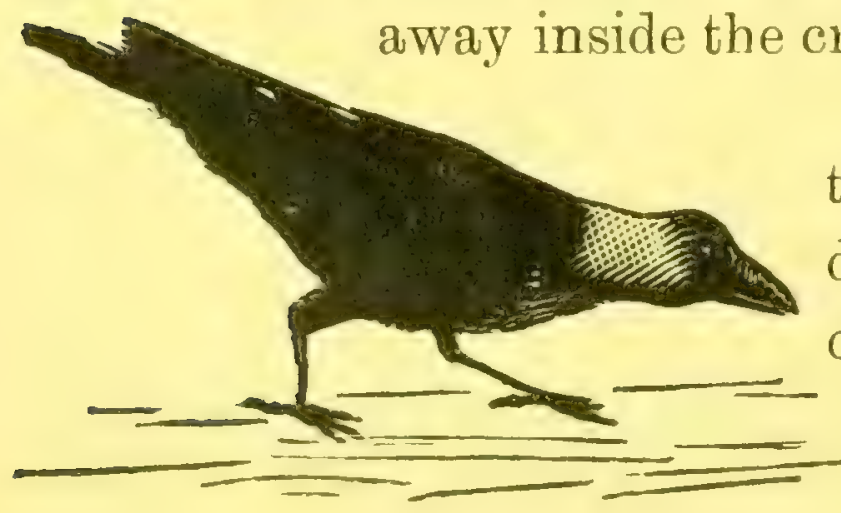

When these birds grow tired of chasing crabs they descend to the very edge of the water and dig out 
of the sand, for a moment exposed by a receding wave, all manner of good things in the shape of crustacea and other small fry of the invertebrate world. This last is a very exciting method of obtaining food, for the crow, if he is not smart about the excavation, runs the risk of being washed away by the next wave. This, however, never happens. Crows are not often caught napping.

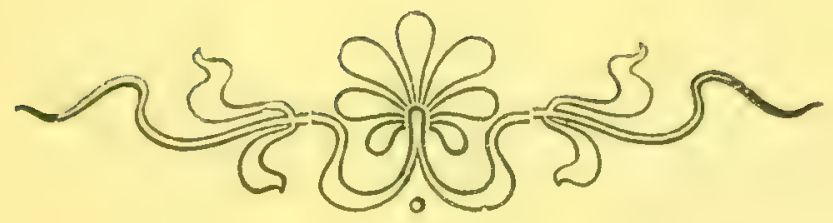




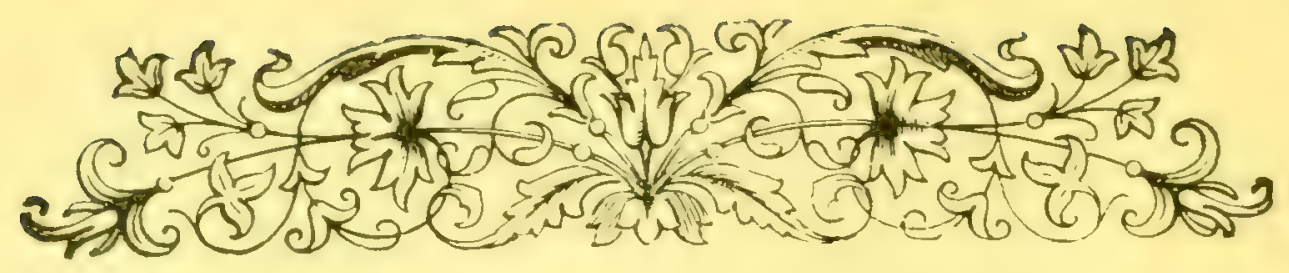

\section{CHAP'TER III.}

\section{HIS DOMESTIC AFFAIRS.}

CokvUs splendens, Esquire, is a family man. He does not keep his spouse waiting for dinner while he is losing money at Bridge in the Club. He is not one of that sort. He is a lind husband and an affectionate father. Although naturally greedy, he will actually allow his wife to take away food from him, a piece of self-denial of which many people refuse to believe the crow to be capable.

If the cock bird is a model husband the female is certainly a paragon of domestic virtue. Did not the sage Manu declare that a Hindu wife should resemble a crow? Does not the kuel select the nest of the grey-necked species in which to place her eggs? Greater compliments than these could scarcely be paid to a bird. For Manu was a man who thought before he spoke. He selected as a pattern of 
wifeliness a hen-crow on account of her very great devotion to her offspring, and surely this is the reason why the koel selects a corvine nest in preference to that of any other bird.

May, June, July and August are the ordinary building months for the crows. The nests seem to be placed indiscriminately in any kind of tree, and sometimes occur on buildings or even on telegraph wires.

A typical nest is composed of " an outer layer of sticks, the thornier the better, lined inside with grass.' Seen from a short distance, it looks like a bundle of twigs thrown hap-hazard into a tree. But all crow's nests are not like this. Just as the bird does not limit itself to one kind of diet so does it not confine itself to one description of material for its nest. A Calcuitta bird has made itself famous

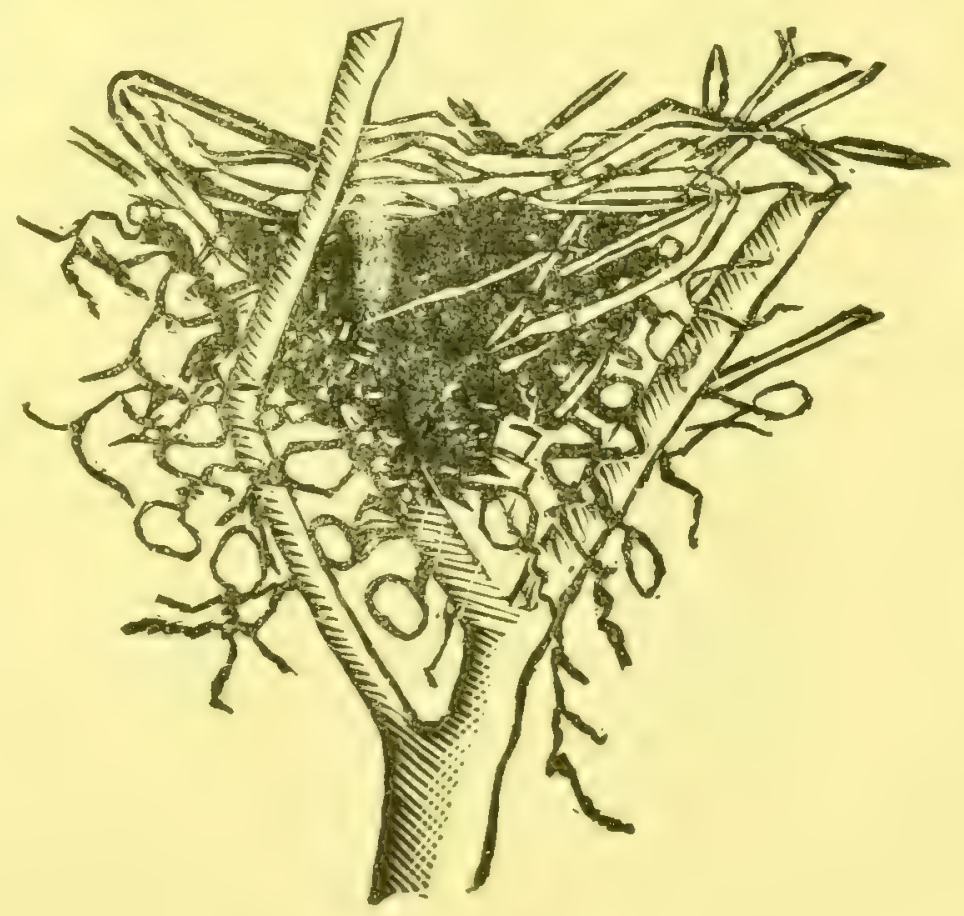


for all time by constructing a nest out of wires used to fasten in the corks of soda-water bottles. Now Bombay is very jealous of Calcutta, and the crows of course ape their betters. Accordingly, the Bombay birds determined not to be outdone by the Calcuttaites. A pair of the former built a nest of gold and silver spectacle frames. The value of the materials used in the construction of that nest was estimated at Rs. 400. I believe I am correct in saying that the Bombay opticians, proud though they be of the local crows, do not encourage this method of nest-building; indeed, to speak precisely, they set their faces steadfastly against these attempts at eclipsing the deeds of the Calcutta birds. Other crows which have a fancy for fire-proof nests steal bits of the wire used in constructing railway fences and utilise these for their nurseries.

At one time I was innocent enough to think that no Madras crow had entered for the nest-building competition and went so far as to state my belief in the columns of the Mailras Mail. The result was a number of epistles from various parts of the Presidency, one and all, vindicating the character of the Madras crow. 
I was assured that the original soda-water wire nest was built in Madras, and certain it is that such a nest was constructed in Madras long ago. Not being an antiquary I am unable to give an opinion as to which city has the right to claim the invention. But the Madras crows can afford to do without it.

To use the words which occur so often in native papers, "a valued correspondent" informed me that a pair of Madras crows constructed a nest out of bits of tin taken from the Tin Bazaar. Another gentleman wrote to say that his father. once took out of a Palmyra tree at Pallavaram a nest made of brandy-bottle wires. T'his, as the Madras Mail sagely remarked, says much for the sagacity of the local crow, but more for the consumption of brandy at Pallavaram.

But we must return to the normal nest and its method of construction. This is an untidy mass of twigs piled together in the angle of a forked branch.

Both birds collect material for the nest, but the husband appears to take no part in the actual building. He merely helps in the gathering of sticks. The male and female keep close company while nest-build- 
ing is in progress. They collect twigs in the same place, and, having each secured one, fly off to the nest together. Upon arrival, the male transfers his stick to the female and hangs about while she fixes both twigs to the nest. This usually occupies only a few seconds; but when a difficult point is reached the hen sometimes takes as long as five minutes in adjusting a refractory twig to her satisfaction. 'T'he male shows great interest in the proceedings, and when he sees that the twigs

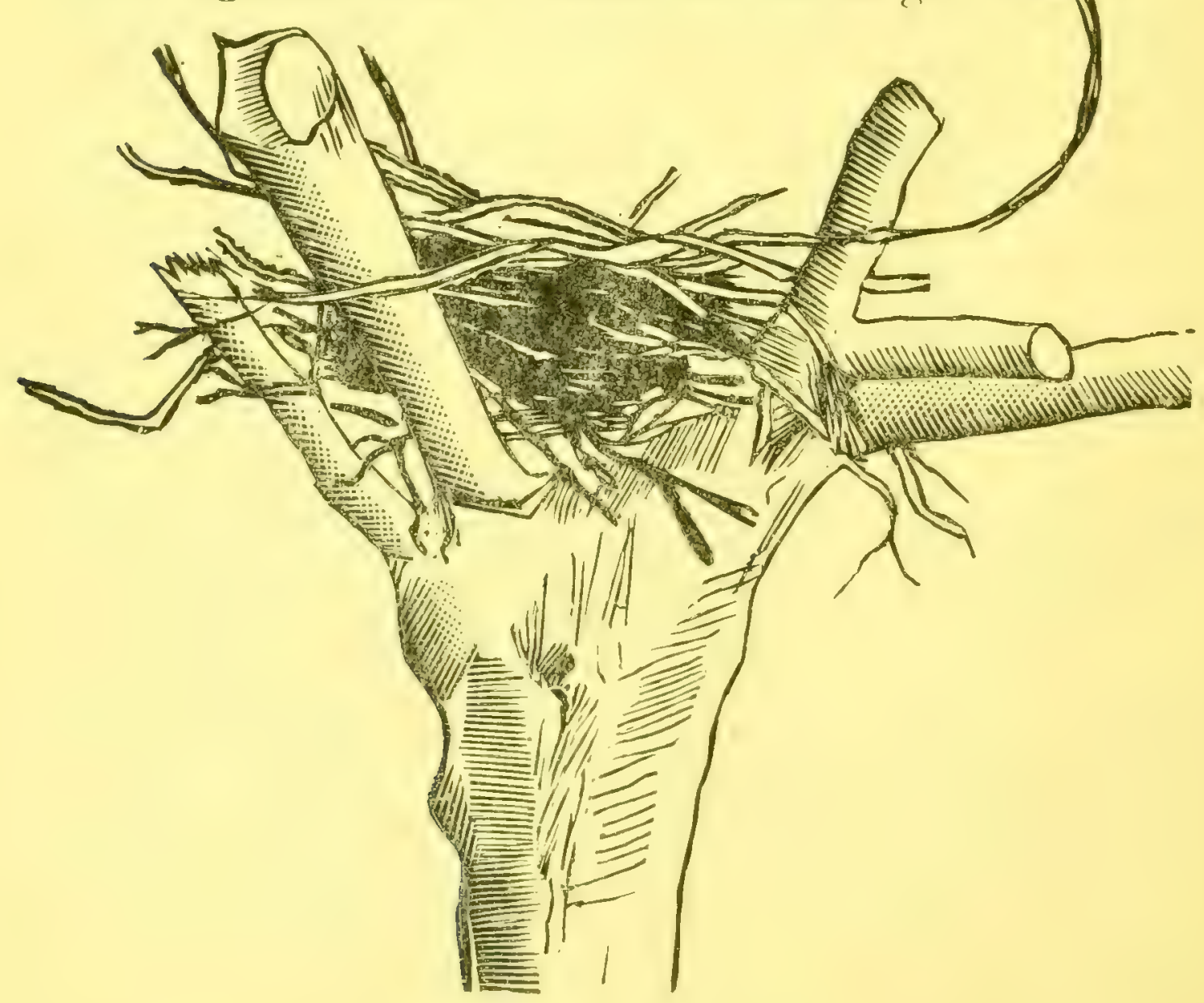




\section{9}

are practically fixed, flies off, wily bird that he is, and thus obtains a start of a few seconds on his wife. She follows him at full speed, but he, thanks to his start, usually finds his twig first, but as he cannot, or, will not, do any building himself, he has to wait, stick in beak, until his better half has found one. If she is unusually slow he will go and hurry her up. If she secures her stick first she does not wait for him, so he has to accompany her empty-handed, or rather empty-beaked. He will not let her out of his sight.

Sometimes, after adding some material to the nest, the birds indulge in a little mild spooning on a house-top or other convenient locality. The spooning takes the form of head tickling. Crows, although great sticklers for etiquette, do not seem to object to such public demonstrations of connubial affection. But these interludes do not last long. Crows, while nest-building, are models of industry. A pair must add to the nest nearly thirty twigs in an hour, and the whole structure is completed in about two days. Crows take fallen twigs by preference, but if these be not available they wrench off green branches. Soon after the nest is completed the hen deposits in it two, three, or four green eggs splotched with 
brown. She then sits on the nest most assiduously. The male appears to relieve her at intervals, but of this I am not sure.

Young crows are just masses of naked ugliness, but the parents watch over them as though they were the most precious things in the world. Under ordinary circumstances the nest is never left unguarded for a minute at a time. While the father

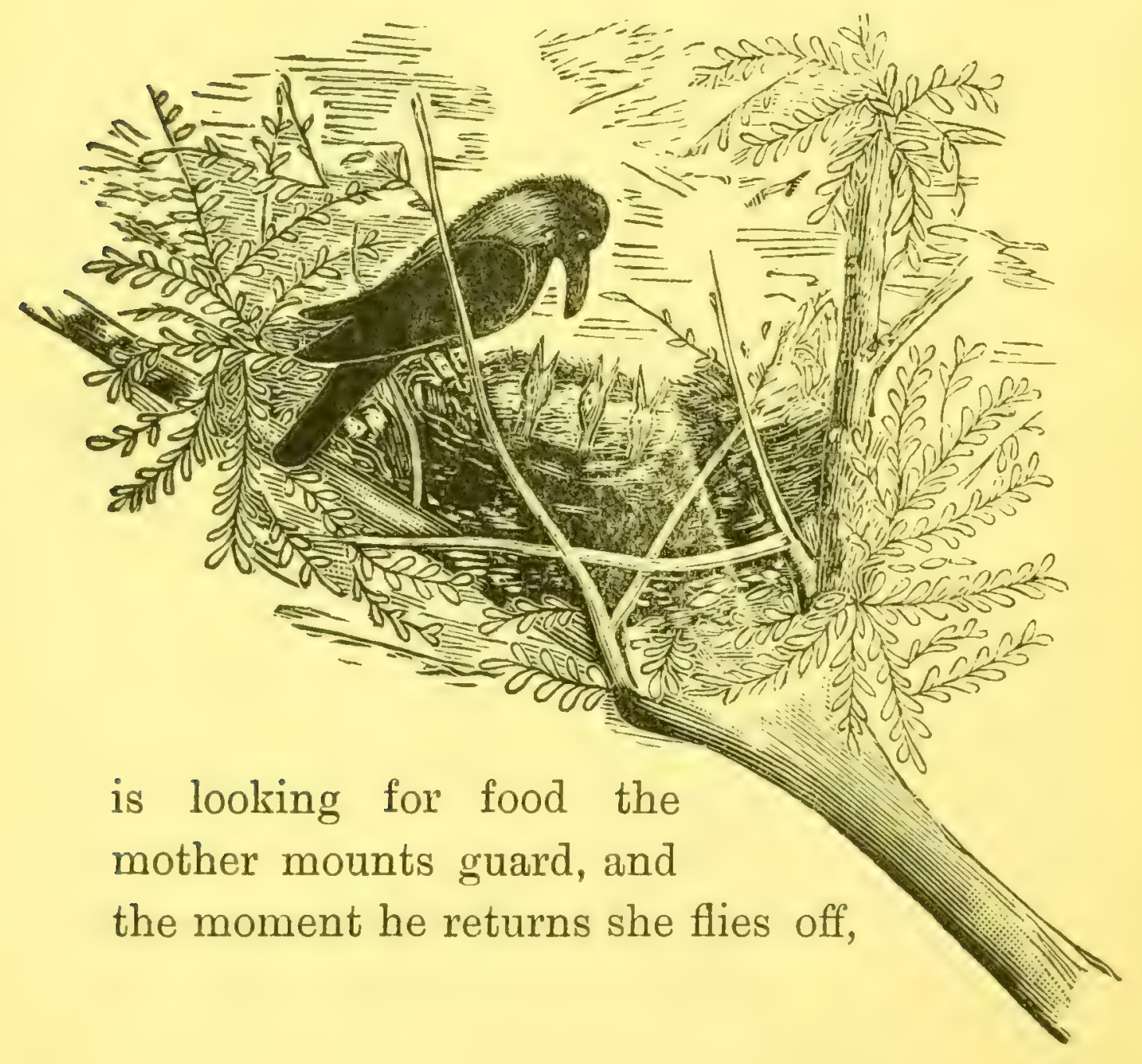


leaving him to protect the young birds. Thus each parent takes its turn at sentinel duty.

The reason of this devotion is not far to seek. It is the penalty of wickedness. It is a case of thieves knowing the ways of thieves. Crows are notorious robbers of nests, neither eggs nor young birds come amiss to them. They know the evil that is in the corvine heart, hence the careful guarding of the young. But I think that there is a limit to the villainy of even a crow. I do not believe that a bird of the vicinity would eat a neighbour's brood, but no outsider crow would feel the least compunction in doing so. This, then, is the chief danger to be feared; a minor one is presented by the kites who make no bones about robbing a crow's nest.

One pair of crows built a nest within twenty feet of my window, hence I was enabled to watch operations closely. The eggs hatched out on the 4 th July and the young birds did not leave the nest until 26 days later. It was amusing to see the parent birds fussing over the young ones, the former had to stand astride the nest for fear of injuring the tender occupants. Crows are naturally active, restless birds, and hence this constant standing over the nest must be very irksome to them. 
Indeed, a crow perched by its nest with open beak and drooping wings looks the picture of boredom. This makes the careful watching all the more creditable to the bird.

I have said that under ordinary circumstances both parents never leave the nest at the same time until the young ones are about three weels old. But any great excitement overcomes their maternal solicitude. Crows are very excitable birds. Suddenly every crow in the neighbourhood, for some reason not apparent to man, starts to caw at the top of its voice and fly wildly about in circles. When thus excited the birds will not stop even to pick up food thrown to them. On such occasions all the birds having young leave the nest and help to swell the uproar. The sight of a koel is quite sufficient to cause the parents to momentarily desert the nest. The koel knows this and utilises the characteristic to deposit an egg in the crow's nest. But of this more anon.

The care of the mother crow for her offspring does not end with nursery days. The little family keep together for weeks after the young birds are fully fledged. 


\section{3}

One family composed of the parents and two youngsters interested me in particular, for it used to visit me with unfailing regularity at the breakfast hour. The father seemed to hold aloof, but the other three were inseparables. The young birds were quite as big as the mother but were easily distinguishable from her. In them the grey feathers of the neck are less sharply differentiated from the black than is the case with adult birds; and the inside of the mouth is red.

The young birds were exceedingly noisy. They squawked without intermission. They entertained the theory that the sole raison d'etre of the mother was to feed them, and their theory is strictly in accordance with the dicta of zoology. They followed their mother everywhere, and behaved like, what they were, spoiled children.

Whenever the mother managed to secure a piece of food, they would try to snatch it away from her. The mother would ruffle her feathers and sidle away from her too-importunate children; then, to the disgust of these, she would swallow, or, at any rate, half-swallow, the morsel of food. 


\section{4}

In a few moments maternal affection would overcome her natural desire for the wherewithal to keep body and soul together, and she would "bring up" the food and thrust it into the gullet of one of the youngsters. It was amusing to watch the inward struggle between her natural greed and her fondness for her offspring that took place whenever she obtained any food. And, to give her her due, love of her children almost invariably prevailed, although sometimes the struggle was a severe one. On one occasion I saw the mother bird swallow, or half swallow, a piece of toast five times before she could bring herself to part with it.

Of course, as the youngsters grew older the mother bird yielded less and less frequently to their importunities.

This care of parents for their young after these have left the nest is an important phenomenon. If it did not exist newly-fledged birds would fare very badly in the fierce struggle for existence. 


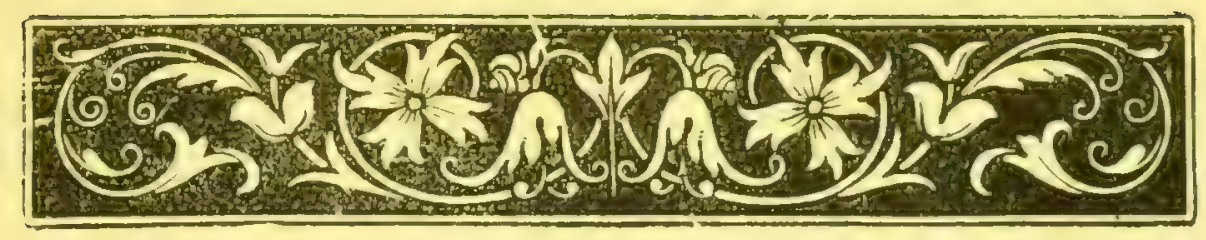

\section{CHAPTER IV.}

\section{HIS HABITS.}

THE crow is an early riser. Some time before "the roseate hues of early dawn" gild the morning skies he is up and doing. His uprising is attended by vociferous cawing. I presume that the first bird to awaken caws into his sleeping neighbour's ear, and so on all along the line, until the whole colony is awake and shouting. Crows roost in company. At night all the corvidae of the neighbourhood foregather, discuss for a time the doings of the day, and then lose themselves in sweet slumber. Crows are not cursed with consciences, hence they sleep the sleep of the just in spite of many crimes. During the whole of a dark night not a single caw will be heard, but when the moon shines occasional "drowsy utterances" may reach the ear. These emanate from some misguided bird who awakes suddenly and while yet drowsy 
mistakes the light of the moon for that of dawn. When he discovers his error he is very angry but does not say much for fear of rousing the rest of the colony.

Crows do not often make mistakes as to times and seasons, but an eclipse of the sun appears to be beyond their comprehension. "When the total eclipse of the sun occurred in January 1898" writes Eha, "the crows of Viziadroog, where I was encamped, were quite taken in and all gathered together in the sleeping tree. When day reappeared, almost before they had got their heads tucked in, they all started into the air with a simultaneous shout of surprise and indignation. They seemed to think a practical joke had been played upon them."

But to return to crows roosting at night. According to Colonel Cunningham "in event of a thunderstorm with vivid lightning or violent gusts of wind, sudden outbursts of expostulation occur at intervals."

This, I submit, is excusable. The most pious of birds ought to be pardoned for indulging in a little profanity under such circumstances. 
The early morning toilette of the crow is not a lengthy affair, for the bird does not bathe until later in the day, presmuably because he does not like his bath-water too cold.

From an hour or so after sunrise until sometime after: sunset the crows may be seen performing their ablutions in any shallow piece of water such as an irrigation channel or a puddle formed by the overflow of a tank.

In Almora, where irrigation channels and tanks are unknown, the crows are sometimes hard put to it to obtain i bath. In the Himalayas water, when it is out of season, is almost as valuable as whisky. Every drop consmmed in Almora had to be carried in a kerosine-oil tin up a considerable hill. My gardener used to keep a little hoard of the precious liquid in an old zinc bath. This the crows converted into a bathing ghat. It was not an idual bathing. place but was better than nothing. The modus operandi under such conditions is as follows: 'The bather: alights on the edge of the bath, and having taken a good look round, for tho crow is nothing if not cautious, he grips hard with his feet and toes 
and plunges his head and neck into the water, agitating them violently and at the same time wagging his tail energetically and gently flapping his wings. There is thus a tremendous amount of splashing, so that the water reaches most parts of his body. Then the bird flies to a tree hard-by, shakes himself as a dog does, and violently preens his feathers with his beak, undergoing the most violent contortions in order to gain access to the more inaccessible parts of his anatomy. Then he again returns to the bath, and repeats the above series of operations. As likely as not, he will return to the charge a third and even a fourth time. Finally he takes a little

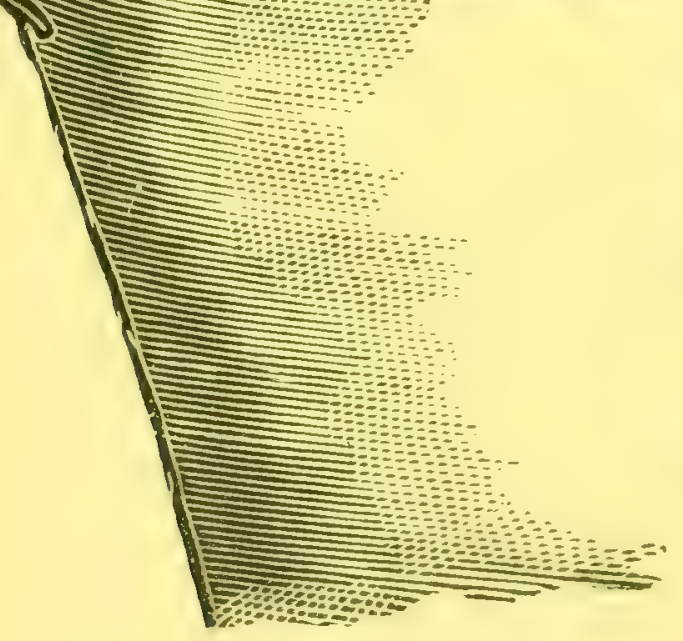

drink, and then it may be known that, so far as he is concerned, bathing is over for the day.

Crows are very particular as to their personal appearance. 


\section{9}

I might almost say "too particular," for they seem unable to draw the line between this desirable characteristic and vanity. Narrow and low is the partition between virtue and vice. There is, moreover, no denying the fact that the crow oversteps the dividing line. He is a vain bird. The natives express this by saying "the crow stuck a pomegranate flower in his tail and thought himself a mighty swell." I have frequently seen the "treble-dated bird "literally gurgling with delight as he contemplated his reflection in the looking glass at the back of my sideboard.

Crows are so anxious that their tribe should make a good show that they set upon and slay all diseased members of their society. But they appear to be able to distinguish between natural and abnormal disfigurement. One often sees mangey-looking crows, innocent of a single feather on the neck, birds which might at first sight be mistaken for: young vultures; but these are not molested. The baldness is, I believe, only temporary.

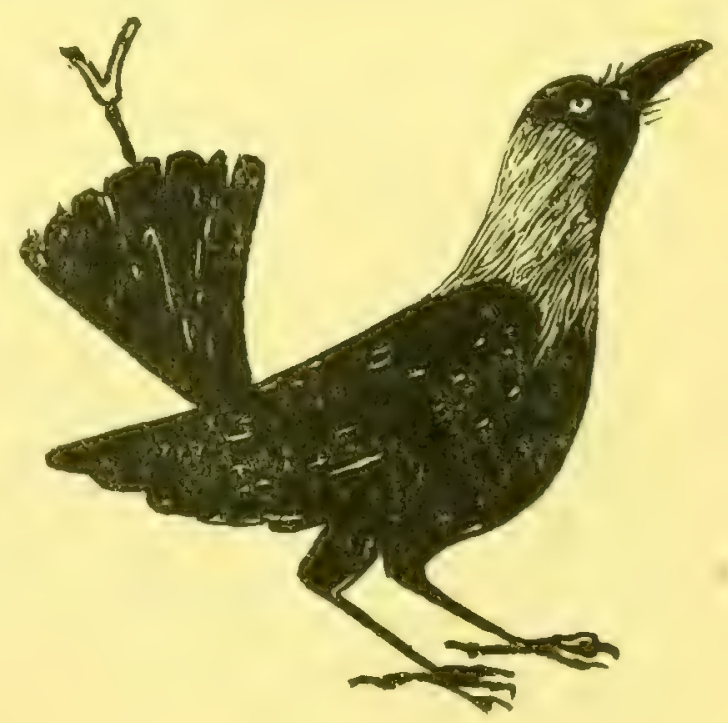


But anything really unusual the crows, like the little nipper, " can't abide." It seems to drive them momentarily mad and they set upon it and peck it to pieces. Some time ago I saw about twenty crows savagely attacking a companion whose legs had been tied to his tail by some mischievous person.

I an toid that a Madras civilian, who retired some years ago, loved not the "ignoble crow." He never lost an opportunity of catching one. Having shaved off its foathers, he would paint the naked bird blue or red and then let it loose. It was immediately set upon and pectied to death by its former friends. 'This habit is said to be utilised by the gypsy folli who esteem crows highly as talle birds. "A live crow" writes Lockwood Kipling, "is spread-eagled on his back, with forked pers holding down his pinions. He flutters and cries, and other crows come to investigate his case and presently attack him. With claws and leak he seizes an assailant and holds him fast. The gypsy steps from hiding and secures and pinions the second crow. These catch two more, the forr catch four' more and so on, until there are enough for dinner, or to take into a town, where the crow-catcher stands 


\section{1}

before some respectable Hindu's shop and threatens to kill the bird he holds in his hand. The Hindu pays a ransom of a pice or two and the crow is released."

Crows are highly social birds, and natives firmly believe that they hold panchayats and punish offenders. They certainly seem to hold what Phil. Robinson calis "cawcusses," but their social instincts do not appear to be so highly developed as those of the rook. 'This is probably the result of their oriental surroundings. The Fast has produced many saints but few citizens.

Crows, in spite of their boldness, are ver'y difficult birds to tame. I have fed the same colony of birds for weslis but have never succeeded in getting a crow to take food from my hand. Colonel Cunningham wis more successful. He writes in his interesting book, Some Lndian Friends and Acquaintances: "At one time I usted to feed a great troop of them every morning and evening; but although they so fully identified ne as a sonce of supply that they never assembled for their daily dole whilst I was absent from Calcutta, and immediately resmmed attendance 
on my return, only two out of the whole throng ever ventured to take anything directly from my hands. They were very proud of themselves for doing so, and used to alight close to me, one on either side on the top of the railings of a flight of steps leading down from the verandah to a long terrace roof a little below. There they would wait in dignified composure, never condescending to join the noisy scuffling of their companions. As a reward for their civilised behaviour they were usually treated to a biscuit each, in place of scraps of bread that were thrown to the mob, and used to wait quite composedly whilst their friends were struggling for the inferior diet, in full confidence that their turn would arrive with the end of the vulgar entertainment. So fully persuaded were they that they would eventually be treated with distinction that pieces of bread handed to them were thrown away as beneath their notice. It was hard to resist the temptation of occasionally teasing them by affecting an intention of defrauding them of their natural tribute. If the biscuits were in evidence from the outset of the entertainment, their minds were at rest, but if kept hidden, it was amusing to note the anxiety that gradually set in as 


\section{3}

the distribution went on, and the growing doubt as to the wisdom of rejecting actual bread in favour of hypothetical biscuit."

I hear that a resident in Madras has been more successful in taming crows than either Colonel Cunningham or myself; and that he has actually induced a crow to perch upon his hand and take food from him. I am further informed that the bird " brings up" that which it has recently sent down "red lane," in anticipation of the better things it is about to receive! What bird, other than a crow, would do such a thing?

Young crows, if taken from the nest, make entertaining but mischievous pets. Lockwood Kipling gives an amusing account of a pair of such birds kept by him. "They were miracles of naughtiness, delighting in sly destruction and odd turns of malice, ever ready to peck at a servant's hurrying heel, and especially given to torment a little dog who hated them. When he had a bone they came daintily stepping together and concerted measures against him, exactly like the stage villains of melodrama, manœuvring and skirmishing with keen enjoyment. On his part, 
the dog learnd to watch and rifle their hiding places. Their delight in bright objects was remarkable. The spoon in my early morning tea, taken in the garden or verandah, was of even more interest to them than my buttered toast, and they were never tired of tugging at my watch chain, in order to get out the watch, a deeply coveted plaything. Frerything of this shining sort that came within reach was promplty buried, dug up awain, re-buried with claborite precantions, and forgotten after a len days. In the hot weather they vastly enjoyed eating and playing with pieces of ice. which they hid for future use. But ice is a treasure fleeting as fairy gold, and the birds showed by the fussy action, sidelong squints, and interrogative turns of the head, which make them such diverting comedians, how deeply they were puzzled br its disappearance. 'simely, surely.

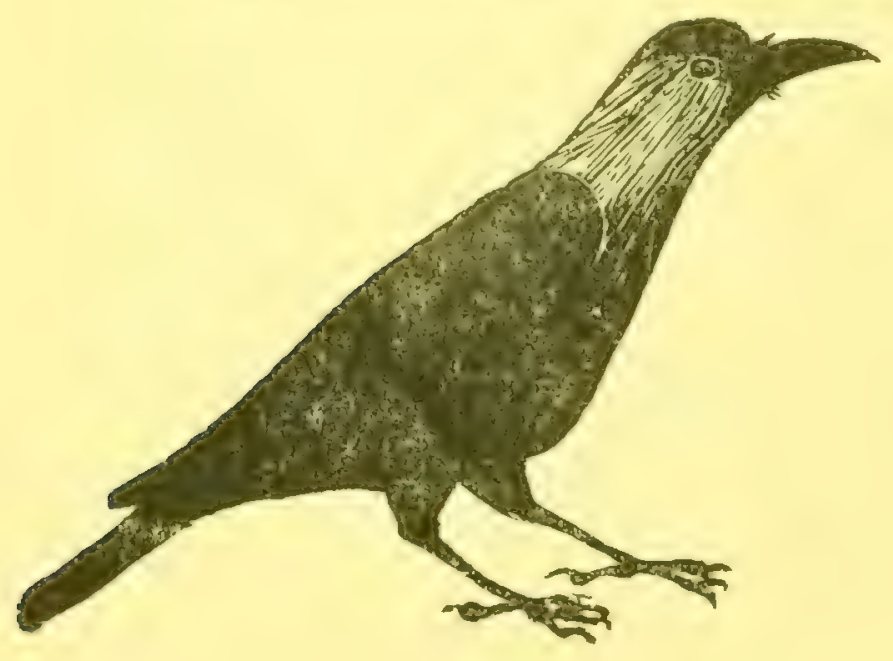

one would seem to say, as he turned up the corner of the matting, 'I hid a cold chunk of shining stuff here,but where is it? Never mind, I will get 
another' So he would hop up to the table and take a fresh piece from the class finger-bowl, itself a great delight to the glitter-loving birds. T'o the last the disappearance of the ice mas a monder. But, like that of some other comedians, their conduct was generally low ; the way in which they allowed themselves to be sent to bed (an old gate in an out-house), though free to fly at will, pacing meekly as good as gold, after a day of variegated crime, was their only lapse into real virtue."

It is a native superstition that the perching of a crow on the top of a house, or its hopping over it, predicts a visit from a friend or relative; but its cawing is the forerunner of some bad news. Now there is some humour about this superstition. I do not think it extravagant to assert that on an average twenty or thirty crows perch in the course of the day on every house in India; what a precession of visiting friends and relatives there must he! Agrain, is it not a delightful belief that every time you hear a crow caw you are in for a bit of bad nows? Fren as I write there are at least a dozen croms shouting bad news at me. Think of the magnitude of the crow population of India and of the birds' fondness 
of cawing, is it then not a wonder that the whole country is not submerged in the sea of bad news which must serge in day and night?

I wonder how many millions of. crows inhabit India. Consider the distribution of the bird. I once maintained that one or other of the species of crow was found everywhere in India, whereupon my readers encompassed me and beset me round like roaring bulls of Bashan. I was given to understand in no uncertain way that there were no crows in the Pulneys, and that the birds were unheard of at Mount Stuart, Anamalais. Not having been at either of those delectable places I was obviously at a disadvantage in the controversy. However, I had the satisfaction of noting that both Corvus splendens and C. macrorhnycus find a place in Dr. Fairbank's list of the birds of the Pulneys, while one "Big Bore" came to my aid as regards the crows of the Anamalais. But let us not bicker over trifles. Our grey-necked friend is certainly found in most parts of the country, and wherever he is found he flourishes like the green bay tree. To repeat what I said in Longman's Magazine: 
The best way to judge of the extent of the corvine population of a town is to take up a position on the roof of the most lofty house in the place, just as the sun is about to sink below the horizon, and, from this point of vantage, watch the crows as they wend their way homeward after the labours of the day.

Crows, although the sworn enemies of man, like to roost in his vicinity. The crows of a locality sleep in colonies on trees preferably near human habitations. During the day they spread themselves over a considerable area, but at eventide they all return to their roosting place.

I once watched the home-coming of the crows from the roof of a house situated on a hillock in the little station of Rajahmundry on the Godaveri river. For the greater part of an hour the birds returned in several continuous streams. Such numbers arrived simultaneously that I found it impossible to count them. However it is no exaggeration to say that upon that particular evening some ten thousand crows flew over my head.

Some came in from the river banks, others returned from the islets and sandbanks which stud 
every Indian river when it is not in flood. Many flew in from hamlets on the opposite side of the broad stream. Nultitudes poured in from the neighbouring fields and jungles.

Considering that I could only see the birds which entered the station at one corner, and bearing in mind that a great many birds never leave the station, the corvine population of that little settlement camnot have been much less than fifty thousand.

Probably over a million crows dwell in Calcutta.

When the birds return at the sunset hour they exhibit no signs of lassitude. On the contrary, they seem most reluctant to retire to rest. There is much cawing and changing of positions before they eventually settle down for the night on the topmost branches of lofty trees.

Crows are early risers. Before the sun has appeared above the horizon their hoarse croaking is mingled with the checrful notes of the drongos and and magpie robins.

"Till in a gathered band of close array,

They take their flight to seek their daily food,"

and to make themselves generally objectionable to man and beast. 


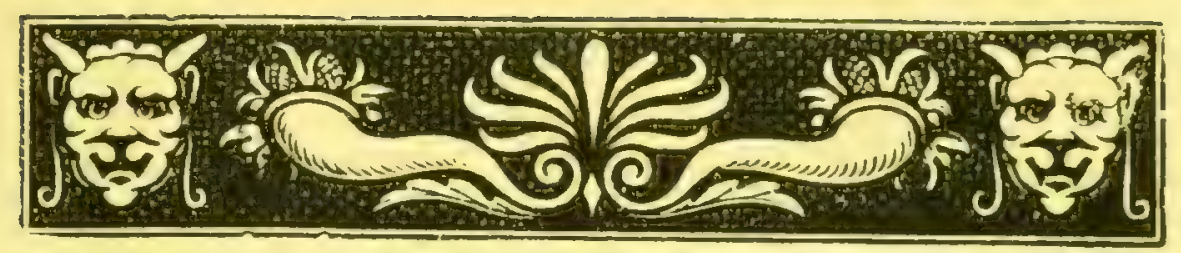

\section{CHAPTER V.}

\section{HIS AMUSEMENTS.}

THE struggle for existence does not press very heavily on the crow. It is obvious that a bird which eats anything will experience less difficulty in securing food than one which can live only on some special form of diet, such as insects, or honey, or fruit. The crow, therefore, has plenty of spare time upon his hands. Being the cleverest and the most intelligent of birds (all ornithologists are now agreed in placing the corvidae at the head of the fowls of the air), he is not content to sleep away his leisure. The crow is a restless bird. When awake he is never still for a moment. He must be doing something; when he is not looking for food he indulges in some game, and his favourite game is 
that of playing mischievous pranks on other birds. He makes a point of pretending to visit the nest of every king-crow in the neighbourhood, merely to annoy the little drongos in possession; but of this more anon. When a crow catches sight of another bird indulging in day-dreams in a tree, it swoops down upon it causing it nearly to die of fright, and then flies away emitting caws of explosive laughter.

Crows, of course, mob every strange bird they see. Like Isondon street boys they cannot tolerate any " bloomin' furriners."

Some time ago I happened in the daytime to put up a large owl from the tree in which it was roosting. A couple of crows caught sight of the night bird, and were on it "like a knife." The owl alighted on the branch of a tree, the crows took up a position on either side of the owl, literally wedging it in. The three birds sat thus for some time, perfect silence being maintained, but the crows looked wickedness itself. The owl was in an unfortunate predicament; it would have dearly loved to make an example of its tormentors, but it knew that if it attacked one of them the other would be able to set upon it from 
behind. The owl therefore decided to make a move. The crows followed.

The owl was at an obvious disadvantage while flying for, its eyes being forwardly directed, it could not see what the crows were doing. It, therefore, soon came to rest on the branch of a mango tree. 'The crows, who were thoroughiy enjoying themselves, mounted guard. Then the owl made a bold bid for freedom. It flew off at a great pace. The crows dashed after it.

At this juncture I lost sight of the comic trio, but I believe that one, at least, of the crows secured a beakful of the owl's feathers, for the pursuers suddenly desisted from the chase and returned to their companions, who greeted them with what appeared to be caws of applause.

A very favourite amusement of the crows is to give chase to a comrade who has been unfortunate enough to secure a piece of food, preferably a slice of toast, too large for him to swallow at gulp.
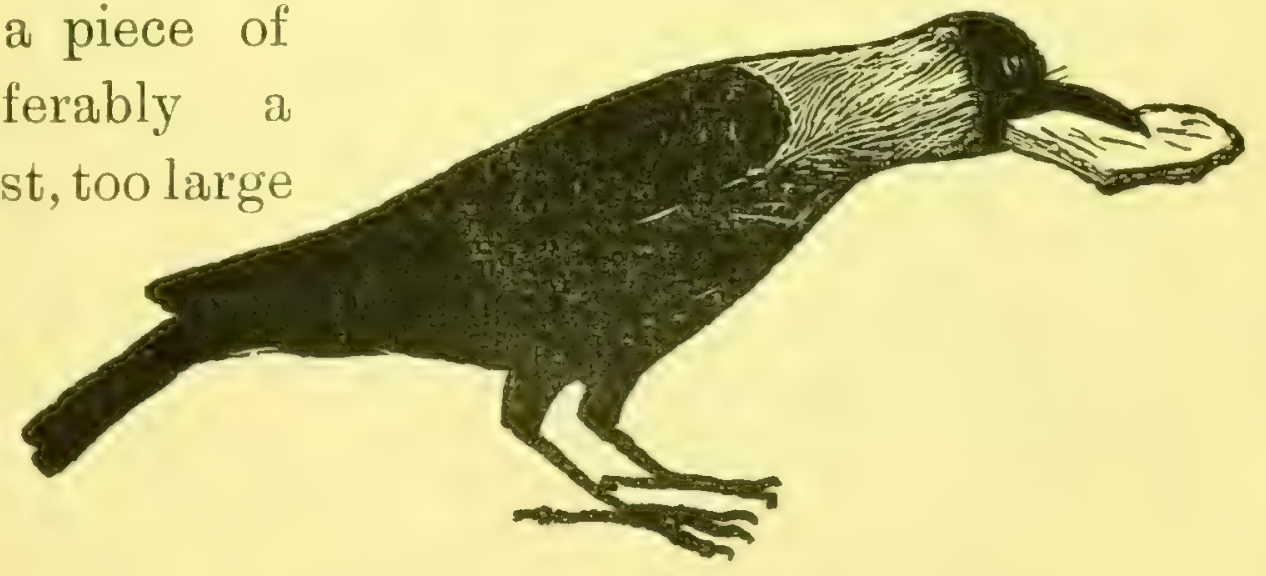
The other crows all know as well as he does that he cannot eat this unless he settle down and secure it with his feet. They determine that he shall not do this, he declares he will. The game thus resolves itself into a bet between the holder and the rest of the players. He bets them he will swallow the toast, they bet him he won't. They chase him from tree to tree. After a little he secures a lead, alights, places a foot on the toast and tries to get a peck at it, but before he can do this his pursuers are upon him. He hurriedly snatches up the toast and again takes to his wings. Eventually he drops the bone of contention, thereupon another bird, taking up the bet, secures the toast and in turn becomes the chased. Before the game is over that piece of toast will have changed hands fifteen or twenty times. With each transfer it becomes more and more battered about, until, I suppose, it eventually becomes sufficiently small and sufficiently soft to be swallowed at a gulp. The swallower then retires and is presently seized with indigestion while the rest of the crows go off and play some other game. One piece of toast will amuse twenty crows for at least an hour. 
It must not be imagined that the crow confines his mischievous attentions to his fellow-birds. Far from it. He is always ready to play a practical joke on any living thing.

Only last week I saw a poor pariah dog, whose ribs were coming through his skin, being tormented by a pair of crows. They had taken away a piece of meat he was eating; not that they were hungry. They made no attempt to devour the morsel; they merely flaunted it before the eyes of the ravenous dog, and when attacked by him. they flew off a little way and again jeered at him.

Some time ago I awoke to find a peacock sunning himself on my verandah. An "ignoble crow" then arrived upon the scene. It was evidently upon mischief intent. It strutted up to the peacock and then jumped over his back. The bigger bird affected not to notice the insult. Then the crow jumped over his head. 'This was too much for the peafowl, who took a peck at the "treble-dated bird" but missed it.

After again hopping over its victim the crow came up from behind and took a gentle pull at one of the train feathers. This offence was ignored. The crow then took a good hard pull. T'he exaspe- 
rated peafowl then turned so savagely upon his assailant that the latter suddenly remembered that it had urgent business elsewhere. Could any assault have been more unprovoked?

Every strange bird or beast which appears in any place is regarded as fair game by the local crows. It goes without saying that man is the favourite butt of the crows, for he is so easily "drawn." With the exception of a good meal, there is nothing which gives a crow so much happiness as disturbing a human being who is desirous of spending a morning in bed. To repeat what I said elsewhere. "When the weary Anglo-Indian determines to spend an 'Europe morning' all the crows in the neighbourhood manage to find this out. How they accomplish this I am unable to say for certain, but I strongly suspect that a douceur to the bearer does the trick.

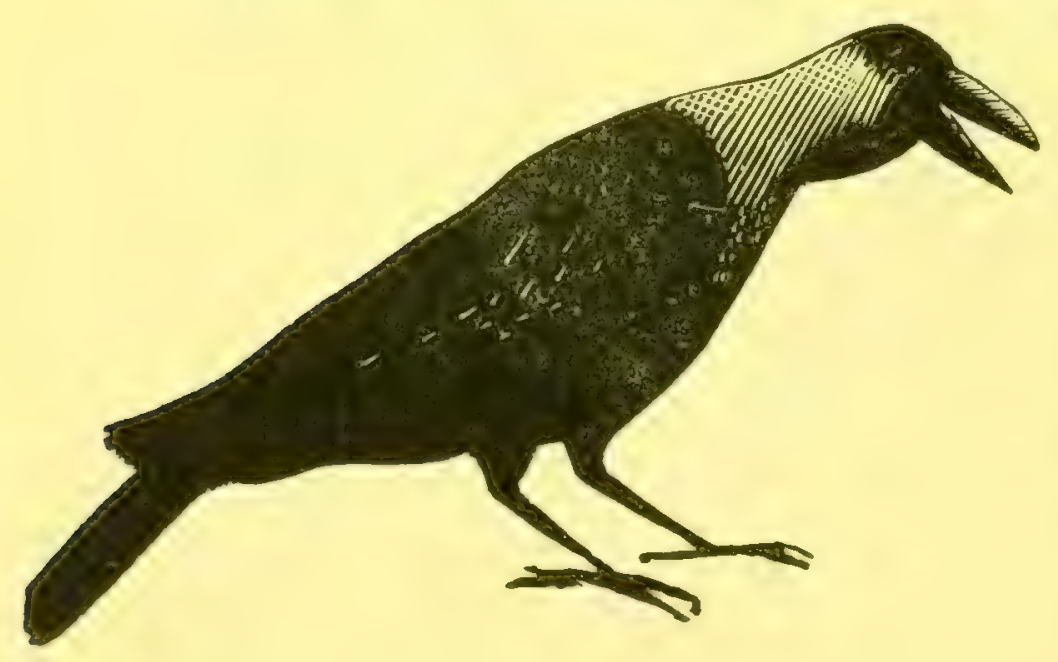

Whether this is so or not it matters little; what does matter is that the crows find out, and take up a position in the verandah at 
dawn and 'squawk' in concert until they awaken the Sahib and make him so irate that further sleep is out of the question."

Crows are especially severe upon golfers. The birds loiter about the links as loafers hang around a public house. When a player makes a long drive, a crow swoops down upon the ball, picks it up in his beak and flies off with it, while the golfer looks on and uses language of the description heard only on golf link.

Sometimes, however, the tables are turned; a golfer occasionally scores off a crow. Recently I had the pleasure of dropping an "approach shot" on to the back of a crow who was swaggering about in the neighbourhood of the " green." Horace Hutchinson tells of a rook in England which was observed tc continue sitting long after the other rooks of the neighbourhood had ceased to do so. The tree in which the nest was situated was growing on a golf links.

The members of the Golf Club investigated the matter and found that the rook was trying to hatch 
a Silvertown golf ball! I have no doubt that crows are similarly taken in. I myself have watched a crow trying for half an hour to break a ping-pong ball in order to get at the yolk.

When it comes to rearing up their young all birds seem to be governed entirely by instinct, intelligence does not seem to come into play at all. Instinct teaches a bird at nesting time to sit upon anything in the shape of an egg. Hence the vain endeavours of one kite to hatch a pill-box.

'Therefore, if any one wish to pay back any debts to a crow that person might do worse than deposit a golf ball in the bird's nest; an old ball will do quite well, nay better than a new one, for it will be more uncomfortable to sit upon.

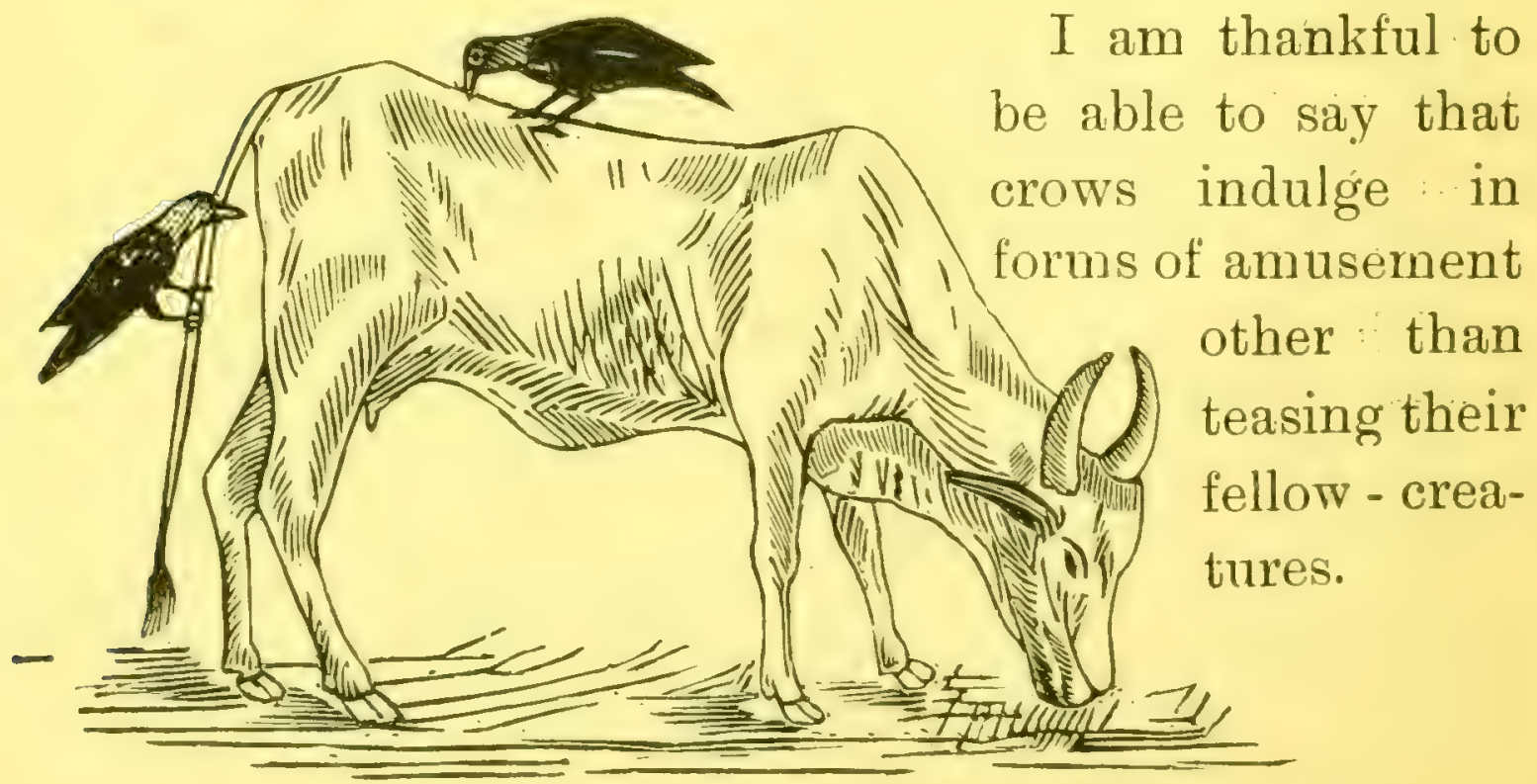




\section{7}

I once saw a couple of these birds thoroughly enjoying themselves sliding down a cow's tail just as small boys love to slide down the bannister.

The Madras crows seem to like paddling in the sea; they delight to stand on the sand left wet by a retreating wave and dare the next to drive them off from that spot. If the wave accepts the challenge and comes up with such force as to threaten to wash the crows off their feet, these birds strut away urconcernedly as though they had caught sight of some object higher up the shore. You will never get a crow to admit that he has been "scored off."

"King of the Castle" is another game in which crows revel. These birds always sit by preference on some high seat, from whence they can look down on and jeer at their fellow-birds. A dozen crows may be seen sitting on any loof which goes up into a point. 'They are very partial to knobs of pillars; as they stand on these they remind one of the pillar saints. In such positions they look as though they were doing penance, and so they are, for such a perch is most uncomfortable; but just as a small boy will sit on a rough, hard wall in preference to a com- 
fortable seat, so will a crow select an insecure perch on the top of a lightning conductor in preference to a secure one on terra firma. Crows are, in many respects, like naughty boys.

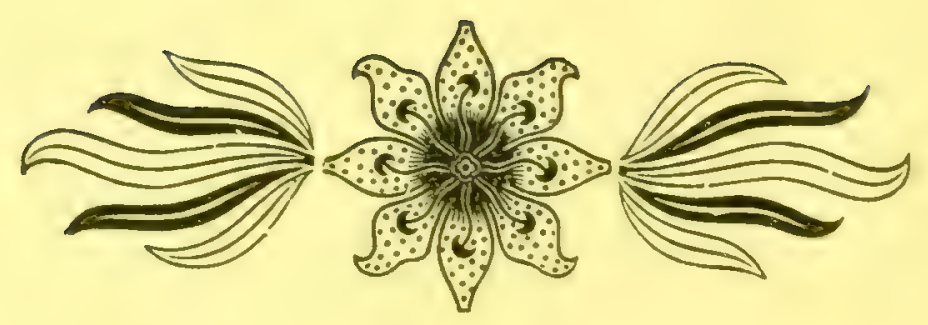




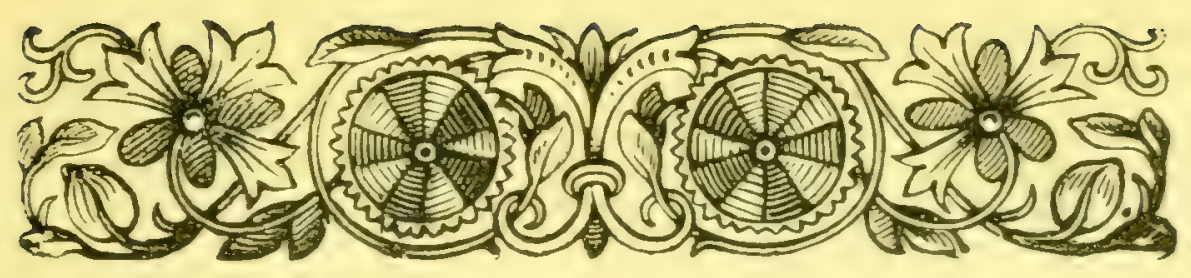

\section{CHAPTER VI.}

\section{HIS FOES.}

THE crow is a bird of many enemies. He is quite the Ishmaelite of the bird world. His hand is against all other species and theirs is against him. Since he will devour the young of almost every fowl of the air, lizards of any age, frogs of all sorts and conditions, and insects of numberless shapes and sizes, these must, one and all, be ranked among his enemies. But such small fry count for nothing. They are foes incapable of harming him, so that the crow, who is perfectly indifferent to public opinion outside his own clique, really does not care two straws whether such insignificant creatures like him or detest him.

With some of his enemies, however, the matter is very different.

Man, for instance, is a foe not to be despised, even by the crow. 
Many human beings habitually shoot crows. Some do so simply because these "treble-dated" birds annoy them, while others do so in order to protect their pockets. These latter suspend the dead crow over a corn field as a warning to the rest of his kind.

In the olden times the crow was reckoned as good shitiar. It is recorded in the Emperor Jehangir's game-book that the royal sportsman bagged over two thousand crows in the course of his shooting expeditions.

I understand that to-day Frenchmen in New Caledonia look upon our sable friends as game of the first water; hence the crows of that convict settlement have become as wily as the serpent, so that if a chassem. bags a brace as the result of a full day's shooting he feels aggrieved if the deed be not forthwith " crowned" by the French Academy.

Thomas Atkins must be numbered among the deadly enemies of the crow. The impudence of the

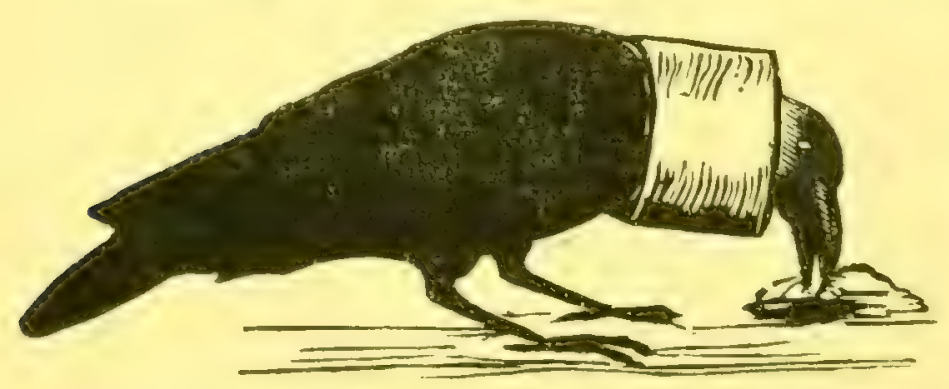
bird naturally puts up the back of a soldier bold, so the 
latter never loses an opportunity of capturing a crow, who, when taken prisoner has to submit to all manner of indignities. One bird was made for his sins to go through life with his neck through a Wills' cigarette tin, in the bottom of which a hole had been punched. The crow who had to wear this collar must have led rather an unhappy life, for, besides, being the laughing stock of his companions, he must have found a cigarette tin a most uncomfortable article of apparel. Another crow, whom I have the honour to number among my acquaintance, has a little bell tied round his neck, which tinkles as he flies about. He has worn this bell for years: it does not appear to cause him any inconvenience and it is possible that he is very proud of the appendage. Crows, as we have seen, are vain birds.

It is perhaps hardy fair to call the kite an enemy of the crow. The two species are certainly constantly squabbling and fighting, but this is rather a matter of jealousy than of enmity. Both birds eat much the same kind of food and obtain it in an equally questionable manner, so that a certain amount of rivalry, accompanied now and again by some bickering, is inevitable. I have witnessed a good 
many fights between kites and crows, but I have never seen any damage inflicted. I suspect that each bird is frightened of the other, so their fighting is very stagey.

The king-crow, however, must without doubt be classed among the enemies of the crow. The little black drongo is the self-constituted policeman of the birds, he is constantly on the look out for offenders which he punishes summarily, therefore, just as the village badmash delights in giving trouble to the policeman and the magistrate, so do the naughty crows do their utmost to annoy the king-crow, who is judiciary and executive rolled into one.

The drongo looks upon the tree in which his nest is situated as his castle and attacks most viciously every man, bird, or beast who dares to approach that tree. I recently saw a couple of kingcrows mob a monkey which had chanced to climb the neem tree in which their nest was placed. The monkey did not stay long in that tree. The kingcrows were on him like a whirlwind, and it was not until the monkey had fled fully a hundred yards that the plucky birds left him in peace. 


\section{3}

Crows, out of pure mischiet, make a point of looking in at every king-crow's nest they come across, just to enquire after the health of the youngsters, and, if the opportunity presents itself, to eat them up. The crows rarely reach the nest. There is no bird more vigilant than the drongo, so that while the aggressor is yet far off the gallant little fellow dashes out to meet him. The crow, not being over valorous, suddenly discovers that he has forgotten something, his card case for preference, and turns back, hotly chased by the king-crows who endeavour to get above him and secure a beakful of feathers. I do not think that they often succeed in getting a punishing blow home, for the crow, when pushed, is capable of showing a fine turn of speed. Be this as it may, one of the commonest sights in India during the months of June, July and August is a couple of tiny specks giving chase to a great crow.

Last hot weather some drongos and crows elected to nest in the same tree, and it chanced that that tree was growing within a dozen yards of my office in the Fort at Madras. 'The Battle of the Yalu River sinks into insignificance when compared with 
the long struggle between the rival birds. The angry screams of the ling-crows as they chased their foes lasted almost without intermittance from 10-30 to 4-30. I took the trouble to time the frequency of the attacks, and found that in thirty minutes the pair of drongos gave chase to offending crows no fewer than sixteen times. Assuming that there were fourteen hours of daylight in the twenty-four, then, every day whilst nesting operations were in progress there were about 4.50 separate fights between those kingcrows and the splendid birds.

There is a certain horned owl which is said to devour crows.

Sober books of natural history assure ns that the owl does do this, so I suppose we must believe it, but it makes a considerable demand on one's faith. What a fine thing it would be to watch the tragedy ; to see on a moonlit night, a great owl swoop silently down upon the crow's nest, upset the sleeping parents and make off with a young one before the old birds have realised what has happened. The rage of these when they had awakened sufficiently to realise what had happened would be a sight for the gods. 
The arch-enemy of the crow is the koel, the bird whose crescendo note drives the European to distraction, but is, to the ears of the Asiatic, divine music. The koel is a cuckoo and hence declines to build a nest or to rear up its own young. (uckoos live up to two mottos. These are: "Never do yourself that which you can make another do for you " and "To do others in the eye is the noblest of all deeds."

Now cuckoos are brilliant criminals. There is some humour in their crimes. They remind me of the dacoits who looted the camp of the late LieutenantGovernor of the United Provinces. As a rule, cuckoos are not content to compel some wretched little bird to do their nursemaid's worts for them; they take a positive delight in making fools of the birds which pride themselves on their vigilance and cuteness.

One cuckoo has actually selected the king-crow, of all birds, as its victim. It is able to perform this astounding feat by dressing up like its dupe. It puts on black plumage and decks itself in a long forked tail. 'Thus, when it is seen side by side with a real king-crow, it is not easy to say which is which. The drongo himself cannot distinguish this cuckoo from 
his own brother so allows it to approach quite close to the nest. As soon as the owner's back is turned the cuckoo, which is playing the rôle of the lion in the ass's skin, deposits an egg in the nest, which the drongo, who is not a mathematician, fails to "spot" on his return.

The koel adopts another method of procedure. The male bird is black and rejoices in a fine long tail. The grey-necked crow cannot bear the sight of the bird, which he attacks the moment he sets eyes on it. This is exactly what the cuckoo desires. He flies up to the crow's nest, making insulting remarks, and turns tail the moment the owners of the nest go for him. The birds then play a grim game of hide-and-seek. The koel, who is a faster flier than a crow, leads the way through thickly wooded places, jeering at his pursuers the whole time to stimulate them to continue the useless chase. The crows make every effort to overtake the aggressor, vowing the most awful vengeance. Presently there comes wafted across the air the welcone sound of "Kuil, kuil, kuil," then the cuckoo knows that the strategy has been successful, that the fell deed has been done, so he hurls some 
parting insults at the crows and flies right away, laughingly answering his wife's cry, and chuckling over the way in which the crows have been duped.

These meanwhile have returned to the nest. Although they are so clever and cunning they cannot count above two. Crows know only of three quantities-nothing, one, and more than one. Hence if there be already three eggs in the nest they will not detect the addition of a fourth. It is not known for certain whether the koel destroys any eggs which are already in the nest. The fact that crow's nests have been found containing but one egg and that laid by a koel, seems to indicate that the koel does destroy the eggs already in the nest, for it is improbable that she deposits her exg in an empty nest.

The surprising thing is that the young koel does not have its neck wrung directly it emerges from. the egg. But all young birds born in nests are much alike. 'They are without exception as ugly as sin.

Nevertheless when the feathers grow the fosterparents should have no difficulty in discovering the nature of the strange nestling. Some authorities think that the crows do make the discovery, but have 


\section{8}

already grown too fond of the youngster to destroy it. Thus Mr. Finn writes "probably by the time that the hen crow awakes to the fact that she has been 'sold again' maternal affection-that powerful force which makes cats foster rats, and wolves babies-has asserted itself to such an extent that she cannot bid the intruder begone." Personally I am inclined to believe that the maternal affection of birds is greatly exaggerated. It is true that birds look well after their young. that they will deny themselves in order to feed them and will fight most bravely in their defence. But is this maternal affection as we understand it? I think not. It is mere instinct. If it be maternal affection how are we able to account for the fact that swifts and swallows in England, when the time for the autumnal migration arrives, desert their late broods, leaving them in the nest to die of starvation? To my way of thinking it is blind instinct that makes the mother bird look after her offspring or whatever else happens to be in the nest. This instinct is so deeply implanted in the bird that she will sometimes give her life to save her young. But in migratory species the migrating instinct is stronger than the 
maternal one. When the two instincts come into opposition the more powerful prevails - the birds migrate and leave their young to perish. If it be not blind instinct that teaches birds to rear up their young, how can we account for the same pair of wagtails bringing up young enckoos in two successive years?

Koel nestlings are not so utterly depraved as some young cuckoos are. They do not seem to be in the habit of murdering their foster-brethren by pitching them over the side of the nest.

Crows certainly appear to be fond of their fosterchildren, they are probably much taken with their long tail. Eha states that he once saw "a pair of crows feeding a clamorous young koel, together with its foster-brother, their own child. It was hungry and clamorous too, but the knel appeared to be the favourite with the parents."

But perhaps the arch enemies of the crow are the wicked divinities who live in Hades, for, according to the Mundas of Chota Nagpur, (and they know as much about the matter as anybody does) the afore- 


\section{0}

said evil divinities are the cause of the nigritude of the splendid birds.

Thus runs the legend: The wicked gods finding fuel cheap in the nether regions set up smelting operations. The fire, smolie and heat annoyed the great god Sing Bonga, wiv issued orders that the furnaces were not to work day and night. This seems very reasonable of him, yet the naughty, naughty divinities refused to obey the order.

Sing Bonga in anger-I quote from Mr. BradleyBirt, who is an authority on Chota Nagpur and its people--" sent two king-crows and an owl to warn them, but they only flippantly waved their furnace tongs at them, trying to catch them by the tails. 'Then Sing Bonga sent a crow. Now the crows were formerly white, but when the unfortunate. representative of the family reached the iron workers they caught him and smoked him black, sending him away thus disfigured to show their contempt for Sing Bonga's orders. 'The crows have never recovered the indignity and have remained black ever since." But crows are not birds to be upset by trifles. They have the good sense to make the best of a bad job. 


\section{1}

"They do not" writes Phil. Robinson, "wear their colour with humility or even with common decency. On the contrary they swagger in it, pretending they chose the exact shade for themselves. In the verandahs they parade the reverend sable which they disgrace; sleek as Chadband, wily as Pecksniff. Their step is grave, and they ever seem on the point of quoting scripture, while their eyes are wandering towards carnal matters. Like Stiggins, they keep a sharp look out for tea-time, and hanker after flesh pots."

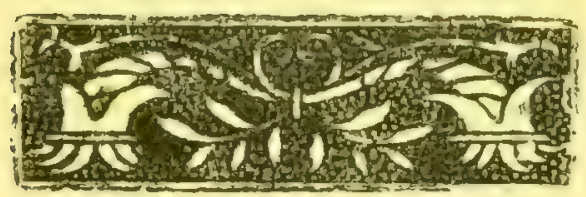




\section{ANNOUNCEMENT.}

\section{It is proposed to issue A BOOK ON THE BIRDS OF INDIA}

By D. Dewar, I C.S., and illustrated from orer 100 Photographs from life specially taken by Capt. Fayrer, I.M.S.

The Aim of the book will be to enable the non-scientific person to identify the birds he continually secs. The book is intended to serve as an introduction to Indian Ornithology. At least one form of every family commonly found in India will be described and illustrated, and a full account of its hahits given.

With this knowledge any person shonld be able to identify without difficulty the other nembers of the family by a reference to the Fauna of British India or to Jerdon's Ornithology.

The book is intended to form a companion to the Fauna of British India and to Jerdon. The classification and nomen. clature will be that of the former of the above two works.

The Plates will be the main feature of the hook. Ther will be reproduced direct by a l'hotographie process and, if sufficicut support is mromised, many of them will be coloured. Siuce the production of good coloured platen in (w) the the preseme al absence of these must depend on the nature of the support pronised before the issue of the book.

The Size $\pi$ ill be about quarto $(10 \times 8)$ to enable sufficient detail in the plates.

The Price will be Rs. 15 or Rs. 20.

It is hoped to issue the book by October nest, and we shall be pleased to register orders now.

HIGGINBOTHA MADRAS AND BANGALORE. 

By the same Author.

\section{ANIMALS OF NO IMPORTANCE,}

R.S. 4-8.

\section{A book dealing with the Common Birds and Beasts of Indian daily life. \\ nanawa}

\section{Some Extracts from Press Opinions.}

"A number of excellent books on Natural history... proceed fiom Anglo-Indian authors; ancertainly this collection of twenty essays on familiar Indian creatures is worthy of its predecessors." The saturday Review.

"In Animals of no Importance, one lights on a treasure trove of literary art... The author of tbese charming essays displays.... a peculiar charm of quiet humour not too subtle for pereeption, nor, on the other hand, extorting mirth in aggressive fashion.... Free from a dull page from cover to cover." - Hloming Post (Delhi).

"A chatty anecdote book....showing a sense of humour and kindly insight. The author talks about such small animals as locusts, spiders, cuckoos, ants, and the animal life of the ocean, giving many anusing stories of their habits and manners." Academy and Literature.

"The sketches are brightly and cleverly written, and there is a ripple of humour running throughout them, which maks them pleasant and amusing reading:"-Indian Daily News.

"Mr. Dewar.... in these twenty chapters on Indian birds, beasts and insects... displays quite remarkable knowledge and insight as well as a very pretty wit.... MIr. Dewar's volume is calculated to give delight to all who are interested in the creatures of God's earth. Its humour will raise many a smile, while its keenness and accuracy of observation should induce many reader's to study more closely. the infinite variety of active life that flutters, creeps and walks around them."-The Madras Mail. 
"The author has something interesting to say about all... he shows the faculty of observation as well as a pleasant style."-Civil \& Military Gazette.

"To every reader of Anglo-Indian newspapers the initials of D. D. are familiar as appended to occasional articles dealing pleasantly with various things in the inexhaustible Nature life of India. Many, therefore, will welcome this collection."-Statesman.

"We may say at once that he has shown most effectually that the commonest animals are of very considerable importance.... and if his book were of no other value, it would do a world of good by showing how much instruction and amusement might be derived from simply watching a fly, a lizard or a bat."-Indian Daily Telegraph.

"MIr. Dewar writes well and with touches of quiet humour; his sketches are not too long, and in several of them he judiciously blends the popular with the scientific by introducing such subjects as protective co-operation, development in relation to evolution, and bird migration."-The Indian Review.

"They are so good that they deserve the distinction of being published in book form. The reader will easily fall under the sway of the writer's charms.... Mr. Dewar's book is as interesting as it is entertaining."-Englistman.

"We may commend the work as an excellent example of 'Natureteaching,' and, at the same time, as showing how the enforced tedium and confinement of Indian hot weather life may be mitigated by the intelligent observation of the ways of the uninvited denizens of the bungalow and its immediate surroundings." Nature.

"Mr. Dewal makes us laugh while he teaches us.... These twenty essays are in all ways delightful." - The Literary World.

To be obtained of-

HIGGINBOTHAM \& Co., .Marlins \&. Bamadore;

THACKER, SPINK \& Co., Calcutte \& Simla, and of all Booksellers. 


\section{G $\mathbb{A} \mathbf{E}$}

\section{By HAWKEYE (Major=General R. Hamilton). DEDICATED TO ALL HIS FELLOW-SPORTSMEN IN INDIA. \\ Price Rs. 2. CONTENTS.}

The Sambur. (ieneral appearance-Beating--Rutting season-Habits-Stalking Weight.

The Ibex. Neilgheriy wild gual-Hahils-Stalkingand baggingSize, breeding season, etc.

A word to Sportsmen. Olservance of a "fence time"-The tiger-Man-eaters rare-How the tiger takes his prey-Sambur's caution-Relish for stale food-Craftiness-Stalking.

The Leopard or Panther. 'Their general character-VarietiesLeopard pitted against a ram--The black leopard-A trap-More pugnacious than tigers - Partiality for dog's flesh.

Bears. Smoking out of den-Ludicrous scenes in bear-shootingGenerally harmless-Narrow escapes--Toddy robbing-Sepoy and bear

Snakes and other matters. The Python-Attack on a monkey -Rock Snakes--How a hare was caught--The Cobra-Warning of presence given by a Persian cat-Size-Anecdotes-The Beaver snake-Description-- The donble-headed snake--Snakes on the Neilgherries.

Midnight experiences. Watch for a tiger-Two successful shotsAn amusing incident-How disappointing!--A fruitless watchExpectation disappointed-An interesting vigil-A vulture and its young-A deer bagged-A regular crow to a little man.

The Tiger. Climbing trees-A stag shot-Dig-linling-Snake charming-Black monkeys-Migratory birds.

\section{Game Laws. -}

Incidents of Shikar. 'The monareh of the glen'-A stag-I'he monarch bagged-Size of tigers-Bears and tigers-A big 'un-The Kobeer man-eater-Buffon's theorics-Rifle-shooting-HaresDeer tribe nomenclature-Fence time on the Neilgherries-Lion shooting in India.

Preseryation of Game. Letter in Friend of India-The S. I. Observer's views-Gun-tax-Fence months-Extinction of game in India.

Review of the proposed Game Act and Minutes of Members of Government.

ADDENDUM. Close season to be observed.

Madras Act for the protection of Game and acclimatised Fish in the District of Nilgiris. 


\section{Higginbotham \& Co., Madras \& Bangalore.}

\section{Indian Natural History, etc.}

Oyerheard. By "Skene Dhu," Author of "The Nighty RS. A.

Mahseer" 150 pages ..

** A charming collection of natural history sketches in the form of bird, beast and fish conversations supposed to have been overheard by "Skene Dhu." The Author, whose Pen-name veils the identity of a well-known Military man, shikari and angler, has a wide and extensive knowledge of all forms of animal life. $\mathrm{He}$ writes in graphic and charming style, and in making his subjects " confabulate" he follows excellent precedents with signal success. From The Madras Mail review.

\section{The Mighty Mahseer and other Fish ;}

or Hints to Beginners on Indian Fishing. By SKENE DHU. Rs. 3-8.

A book on Angling in India. It is illustrated by a number of clear, well-drawn plates, which figure in detail the better hnown fish found in Indian Waters.

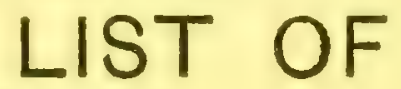

I. The Mahseer.

II. The Carnatic Carp.

III. Barilius Bola.

IV. Barilius Caranensis.

V. The Black Spot.

VI. The Chilwa.

VII. The Butchwa.

VIII. Megalops.

IX. The Murral.

X. Wallago Attu.

XI. Silundia Gangetica.

XII. The Goonch.

XIII. Labeo.

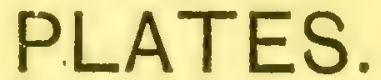

XIV. The Mirga.

XV. The Olive Carp.

XVI. Notopterus Chitala.

XVII. Indian Gudgeon.

XVIII. Notopterus Kapirat.

XIX. Etroplus Suratensis.

XX. The Bahmin.

XXI. The Nair Fish.

XXII. Spoons, Live-bait flight and Spinner.

XXIII. Scale of Hooks.

XXIV. Float, Knot and Line splicing. 


\section{Higginbotham \& Co., Madras \& Bangalore.}

RS. A.

Thomas' Rod in India, being hints how to obtain sport, with remarks on the Natural history of fish and their culture, and illustrations of fish and tackle by H. Sullivan Thomas, Third Edition _. $\quad$.. 114

Secondhand Copy of the second edition of above, containing the hand coloured plates .. $\quad . \quad$ Scarce.. 180

Tank Angling in India, by H. S. Thomas, with illustrations 50

The Angler's Handbook for India, compiled by the late G. H. Lacy, B.S.C., being the North Punjab Fishing Club Anglers Handbook, thoroughly revised and corrected up to date with several new chapters and additional information by Dr. E. Cretin, B.MI.S., 4th Edition, with Map and illustrations, 1905

Fishing, by H. Cholmondeley Pennell and others. Badminton Library.

Vol. I-Salmon, Trout and Grayling, 158 illustrations.. 54

Vol. II-Pike and other coarse fish, 133 illustrations .. 54

Sea Fishing, by John Bickerdyke, W. Senior and others. Badminton Library, illustrated . .

Angling on the Kumaon Lakes, with map of calch lake, by Deputy Surgeon-General W. Walker

The Fishes of India, being a Natural history of the fishes known to inhabit the seas and fresh waters of India, Burma and Ceylon, by Francis Day. Atlas only, containing 77 folio plates, as new

* * Each plate contains 5 or 6 figures

The Fishes of Malabar, by Francis Day. Text and plates in 1 vol. Bound in morocco line, as new .. .. 75

Trout Fishing, by W. Earl Hodgson, with a frontispiece by by H. L. Rolfe in colour, and a facsimile in colour of a model book of flies, for stream and lake, arranged according to the months in which the lures are appropriate,

\section{Higginbotham \& Co., Madras \& Bangalore.}




\section{Higginbotham \& Co., Madras \& Bangalore.}

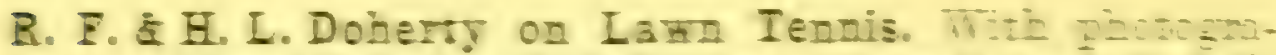

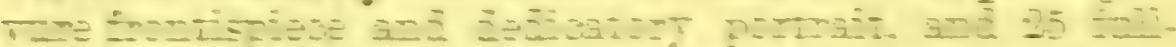

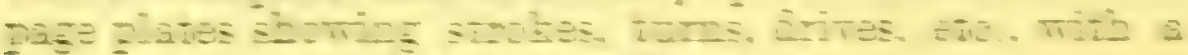

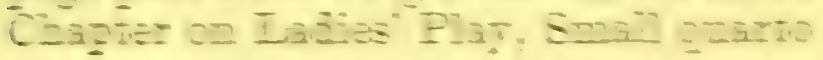

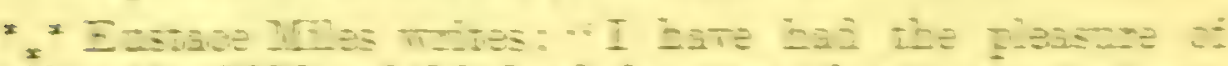

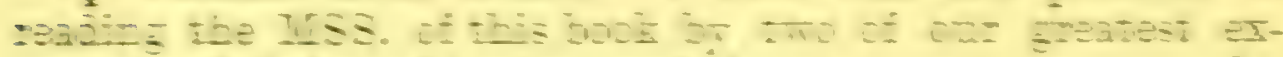

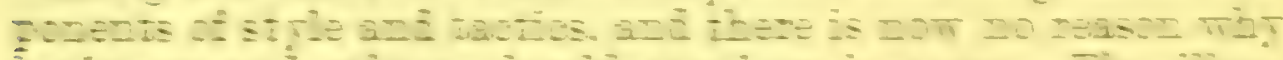

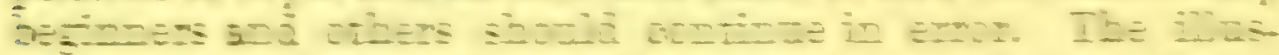

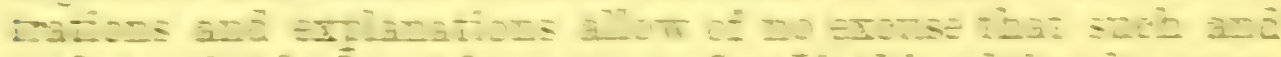

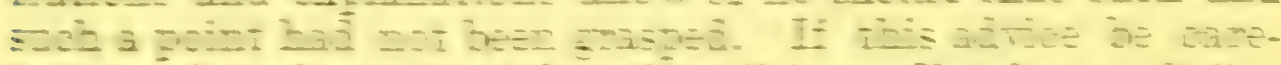

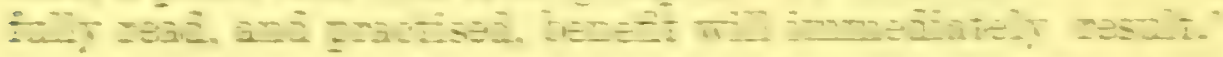

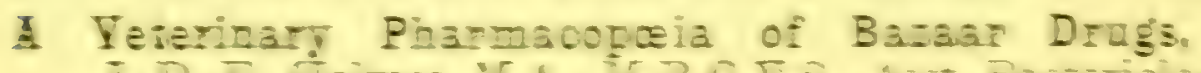

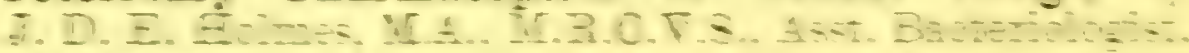
Yultes:

Pasiage $A \leq-3$

I

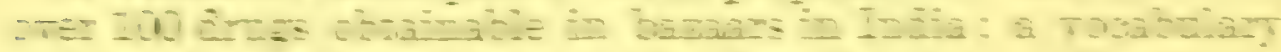

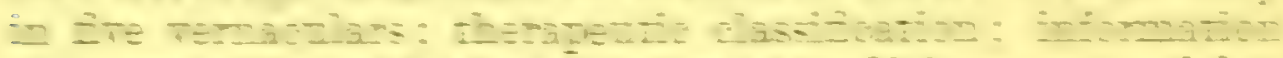

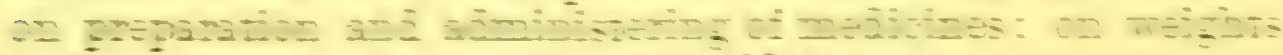

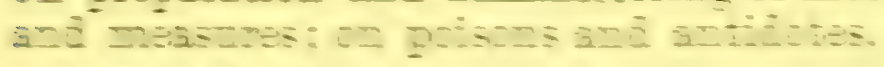

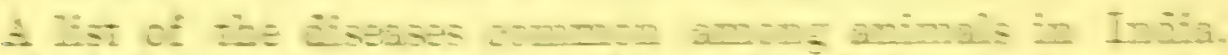

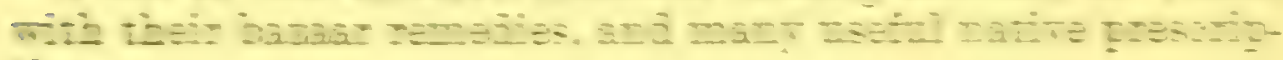
ri:-

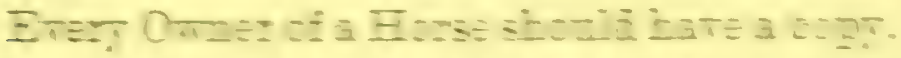

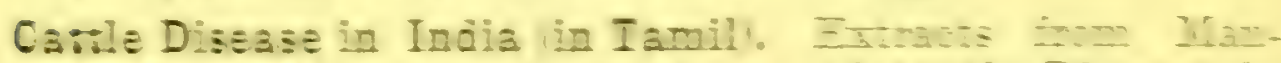

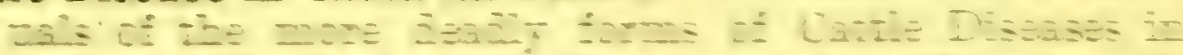
I

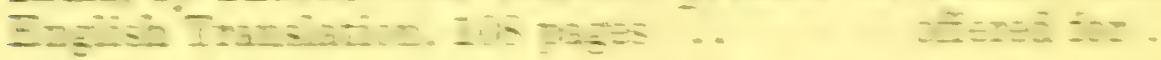

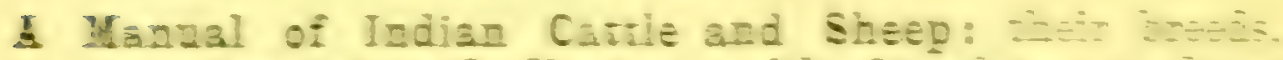

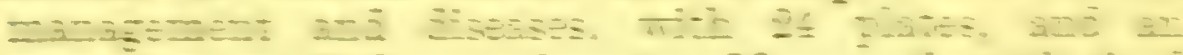

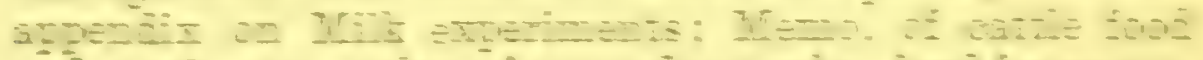
s

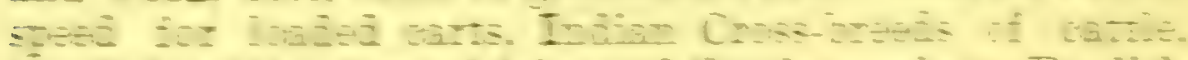

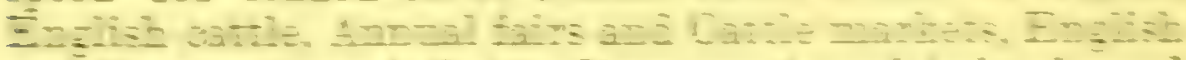

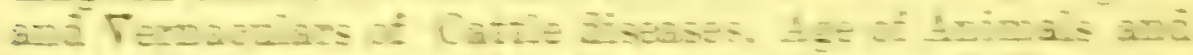

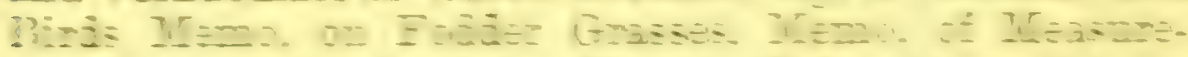
=EI.

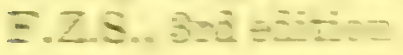

Higzinhotham f Co.. Madras of Bangalore. 


\section{Higginbotham \& $\mathcal{C}_{0} .$, Madras \& Bangalore.}

Adam's Diseases of the Horse, a Treative on the Diseases, RS. A. Lameness and Accidents to which the Hnrse in liable in India, with 8 plates, 600 pages. Recently reduced from (postage As. 6) Rs. 8 to ..

** As the whole has been written in India, it is hoped that this book will prove to be of especial use to those interested in Horses in this country. The price, Rs. 5, is les. than half that of other books on Horses in India. and for actual use the book is far more practicable.

Stable Management and Exercise. A hooli for HorseOwners and Students. By Capt. M. Horace Hayes, F.R.C.V.S. Second Edition, illustrated by numerous Reproductions of Photographs taken specially for this work $10 \quad 8$

"Captain Hayes-who may justly claim to be the first authority now living on all matters connected with the horse -is always relcome, and the more so because each successire volume is a monument of "the reason why.' "- Count? Gentleman.

Points of the Horse. A familiar treatise on the Confirmation, Movements, Breeds and evolution of the Horse. By Capt. II Horace Hayes, E.R.C.V.S. Third Edition. Super royal 8vo, cloth, gilt top ..

The present Edition has been thoroughly revised and contains numerous additions. including specially-mritten Chapters on the Breeds of English and Foreign Horses, with over 660 beautiful Illustrations reproduced from photograph. the larger number of which were taken by the Anthor and have never before been published.

"An elaborate and instructive compendium of sound knowledge on a subject of great moment to all owners of horses, by a writer of established authority on all matters connected with the horse."-Times.

"We hail the advent of a work on the subject by such a pastmaster of the arts hippic as Captain Horace Hayes, late of 'The Buffs,' and a Fellow of the Royal College of Veterinary Surgeons, the author of several of the most simple and thoroughly instructive treatises upon riding, breaking and veterinary treatment of the horse."-Land and Water.

Higginbotham \& Co., Madras \& Bangalore. 


\section{Higginbotham \& $C_{0}$. , Madras \& Bangalore.}

RS. A.

Riding and Hunting. By Capt. M. H. Hayes, F.R.C.V.S. Fully Illustrated with upwards of 250 Reproductions of Photographs and Drawings. Demy 8vo, cloth .. 140

Yeterinary Notes for Horse-0 wners. An Illustrated Manual of Horse Medicine and Surgery, written in simple Language. By Capt. M. H. Hayes, F.R.C.V.S. Sixth Edition. Revised and enlarged .. .. .. 1

The Horsewoman. A Plactical Guide to Side-Saddle Ridincr. By Mrs. Hayes. Edited by Capt. M. H. Hayes. Second Edition, Revised and enlarged with 133 photographic illustrations added, 1903

"A large amount of sound, practical instumction, very judiciously and pleasantly imparted." - The Times.

"This is the first occasion on which a practical horseman and a practical horsewoman have collaborated in binging out a book on riding for ladies. The result is in every way satisfactory, and, no matter how well a lady may ride, she will gain much valuable information from a perusial of 'The Horsewoman.' The book is happily free from selflaudatory passages."-The Field.

Veterinary Aide Memoir and Receipt Book. For the use of non-professional Horse-owners in India, by BrigadierGeneral W. H. Ryves. 8vo. Cloth $\ldots$. . 0

Diseases of the Elephant and Camel, condensed from Dr. Gilchrist's 'Treatise, with list of drugs. by Maja H.P. Hawkes, A.A.C.G. Published by Govenment authority

Plain Hints on the Diseases of Cattle in India, with plates, by Vety.-Capt. J.Mills. Second Edition, Revised and enlarged

"Raoul"-Small Game Shooting in Bengal, and some of theiv habitat, with 4 full-page illustrations.

Contents: Snipe-Partridge-Quails-Elorican-Geese-Duchsl'eal-Coots-Saruses-How to Cook the Game, etc.

\section{Higginbotham \& Co., Madras \& Bangalore.}




\section{Higginbotham \& Co., Madras \& Bangalore.}

RS. A.

Horse Breeding and Rearing in India. With Notes on Training for the Flat, and Across Country, and on Purchase, Breaking in and General Management. By Major John Humfrey, B.S.C., F.Z.S. Crown 8vo, eloth ․ 3 8

The Griffin's Aide-de-Camp, by " Blunt Spul's," with an addendum, containing hints on the education of the Horse and Veterinary Pharmacopoia. Sixth Edition, with anatomical plate of the horse and illustrations .. in this edition.

** "Vagrant's" article on Burmah Ponies is includrd

Indian Horse Notes. An Epitome of useful Information arranged fcr ready reference on Emergencies, and specially adapted for Officers and Mofussil Residents. All Technical Terms explained and Simplest Remedies selected. By Major C——, Author of "Indian Notes about Dogs." Fifth Edition, revised and considerably enlarged. F'cap 8vo, cloth

de to Examination of Horses for Solundness for Students and Beginners. By J. Moore, F.R.C.V.S., Army Vety. Dept., Vety. Officer, Remount Depôt, Calcutta. F'cap 8vo, limp cloth.

Practical Hints on Horse, Harness and Trap. By Donylas

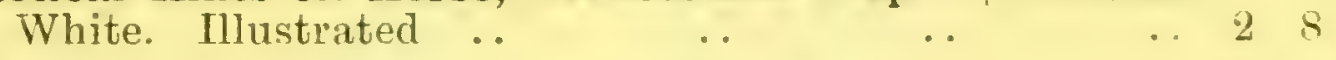

The Asian Pocket Book. Annually in May .. _. T A Bobbery Pack in India, by Capt. Julian _. $\quad \ldots \quad 1$ \&

Dogs for Hot Climates. A (ruide for Residents in Tropical Countries as to suitable Breeds, their Respective Uses, Management and Doctoring. By Vero Shaw and Capt. M. H. Hayes. With Illustrations

"The authors of 'Dogs for Hot Climates' show in a concise practical way how to treat dogs ont here, and what breeds best stand the climate. The book should be on every one's table, for sensible treatment will save the life of many a valuable and muchloved pet."-Indian Planter's' Gazette. 


\section{Higginbotham \& Co., Madras \& Bangalore.}

Ris. A.

Indian Notes about Dogs: their Diseases and Treatment. By Major C- Seventh Edition. F'cap 8vo, cloth 18

The Management and Breeding of Dogs in India, and the Points to Breed for. By 'Kader' an Associate of the Fnglish Fennel Club. Crown 8ro, eloth

Big Game shooting. "Country Life" Library of swort. 2 vols. 1905 .. $\quad \ldots \quad$.. 2114

Rowlanù Ward's Records of Big Game _. $\quad$. 26 it

Hume and Marshall's Game Birds of India, in :3 vols., with coloured plates $\quad . . \quad$.. Scarce, offered for $125 \quad 0$

Marshall and de Niceville's Butterflies of India, Burmah and Ceylon, with numerous coloured and photographic plates, 3 vols.

** Complete sets are very scarce. (nd volumes are sometimes obtainable at comparatively small prices.

Hampson's Moths, in 4 vols. Fanna of British India $\ldots 70 \quad 0$ Taxidermy --

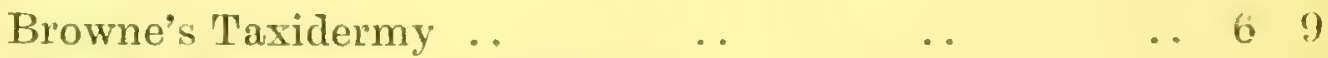

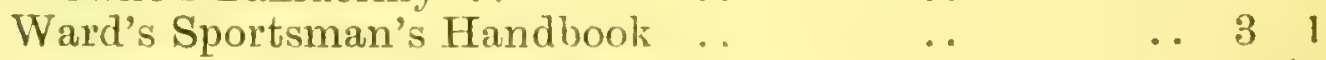

Taxidermy "Work" Handbooks.. $\quad$.. $\quad$.. 0 1.

Bird and Animal Stuffing by Garduer $\quad \ldots \quad \ldots \quad \ldots$ 1.2

Jerdon's Birds of India, being a Natural history of all the birds known to inhabit continental India. Two volumes in three, 1877

Scarce 850

Jerdon's Illustrations of Indian Ornithology, containing 50 figures of new unfigured and interesting species of birds chiefly from the South of India. Printed in Madras in

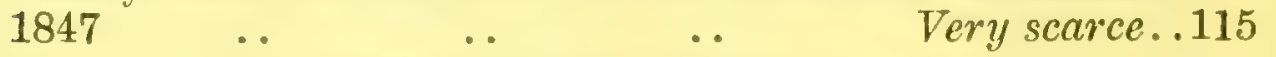

* * The plates are beautifully hand coloured.

Also in parts (4 completing the book) -

Part I. none. Part II. none.

Part III. With 14 coloured plates

Part IV. With 10 coloured plates

$\begin{array}{llrr}\ldots & \ldots & 10 & 0 \\ \cdots & \ldots & 8 & 0\end{array}$




\section{Higginbotham \& Co., Madras \& Bangalore.}

RS. A.

A Handbook of the Birds of British Burmah, including those found in the adjoining state of Karemee, by Eugene W. Oates, in 2 vols., 1883. Published at $£ 2-2-0$.

New copy offered for . . $21 \quad 8$

The Fauna of British India. Including Ceylon and Burma -Birds, Vol. I. Rs. 15. Vol. II. Rs. 11-4. Vol. III.

Rs. 11-4, Vol. IV . $\quad$.. $\quad \ldots .114$

A Catalogue of the Birds of Sind, Cutch, Kathiawar, North Gujarat and Mount Aboo. By Capt. E. H. Butler, 20

The Game, Shore and Water Birds of India, by Col. A. LeMesurier, Second Edition, re-written and enlarged, with numerous illustrations. quarto, 1904 . 18 (;

Garden and Aviary Birds of India. A Handbook for Field Naturalists and Bird-fanciers. By F. Finn, B.A., F.Z.S., Member of the Ornithologist's Union. Fully Illustrated. Crown 8vo, cloth

In preparation.

Ward's Sportsman's Handbook. Or practical coilecting, preserving and artistic setting up of Trophies and Specimens, together with a guide to the Hunting Grounds of the World, by Rowland Ward, F.Z.S. Eighth Edition, Illustrated. .

The Sportsman's Book for India. With contributions by Lt.-Genl. Sir 1Iontagu Gilbert Gerard, K.C.S.I., General A. A. Kinloch, C.B., Lt.-Col. Bairnsfather, Najor ( . H. Clay, Major Neville Taylor, and W.S. Burke (Editor of Indian, Ficld), edited by F. G. Aflalo, F.R.G.S., F.Z.S. Illustrated with Photographs and Maps

$1904 \ldots 1512$

Sport and Adrenture in the Indian Jungle. By A. Mervyn Smith, with Illustrations from Original Drawings and

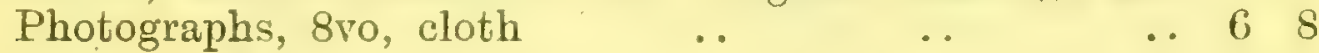

Sterndale's Mammalia of India and Ceylon, by R. A.

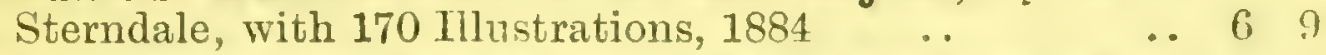

Sanderson's Thirteen Years among the Wild Beasts of India: their haunts and habits from personal observation, with an account of the modes of capturing and taming elephants. Sixth Edition, Illustrated, 12s. 6d., new copy for

Higginbotham \& Co., Madras \& Bangalore. 


\section{Higginbotham \& Co., Madras \& Bangalore.}

Nicholson's Indian Snakes. An elementary treatise on ophiology with a descriptive catalogue of the snakes found in India and adjoining countries, by E. Nicholson, Surgeon, A.M.D. With 20 plates, each containing many figure's, many being hand-colourerl

RS. A.

Fauna of British India, including (eylon and BurmahFishes, by Francis Day. Vol.1. Ks. 15. Vol. II. . 150

Baker's Rifle and Hound in Ceylon, illustrated .. 210

Baker's Wild Beasts and their ways, by Sir W. Baker, illustrated

A Naturalist on the Prowl. By E. H. A. With s0 Illustrittions by R. A. Sterndale, F.R.G.S., F.Z.S., Author of "Nammalia of India." Cloth, gilt top .. $\quad$. 48

The Tribes on My Frontier. An Indian Naturalist's Foreign Policy. By E. H. A., Author of "A Naturalist on the Prowl," etc. With 50 Illustrations by F. C. Macrae. Cloth, gilt top

Behind the Bungalow. By E. H. A., Author of "Tribes on My Frontier," and "A Naturalist on the Prowl." With 53 clever sketches by the Illustrator of "The Tribes." Sixth Edition. Cloth, gilt top ..

The Common Birds of Bombay. With sketches by the Author, E. H. Aitken..

\section{INDIAN SPORTS AND PASTIME}

Hockey

Hockey. By F. S. Cresswell. "All Englan." Series .. 012 Hockey, historical and practical. By J. N. Smith and others. 59 illustrations. The "Isthmian" Library . 312 Hockey Rules. Official Edition ..

\section{Polo}

Riding and Polo. Badminton Library $\quad$. $\quad \ldots .54$ Polo. "Country Life" Library .. 1905.. 1015 Miller's Modern Polo. Edited by Capt. M. H. Hayes. Enlarged Edition .. $\quad . .14 \quad \ldots 140$ The Game of Polo, by T. F. Dale (Stoneclink) 


\section{Higginbotham \& Co., Madras \& Bangalore.}

\section{Lawn Tennis-}

RS. A.

Great Lawn Temnis Player's: their methods, illustrated by means of "Action Photographs," by Beldam, G. W. and R. A. Vaile .. 1905.

** There are 229 "Action Photographs" at 1/1000th part of a second, taken in actual play, of all the prominent players of the day in the execution of their most characteristic strukes.

The Dohertys on Lawn Tenui-. with 25 full-page phutugraphic plates, showing grips, services, returns, smashes, etc.

Modern Lawn Tennis, by P. A. Vaile, illustrated by cxplanatury diagrams and by action photographs taren expressly for this work . . . 1904.. Tennis, Lawn Tennis, Rackets and Fives. Badminton Library

Tennis Rules. Official Edition

Lawn Tennis. "All England" Series

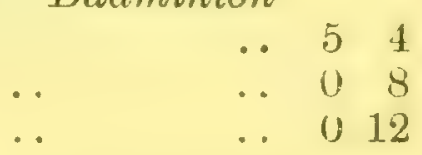

\section{Driving-}

Driving, by the Duke of Beaufort and uthers. Budminton Library

Hints on Driving, by Capt. Molley Knight

\section{Gymnastics, etc.-}

Sinndow's strength and how to obtain it, new edition, with new charts, illustrations, etc. $\quad \ldots \quad \ldots \quad \ldots \quad 1905 \quad \ldots \quad 2 \quad: 3$ Checkley's Natural System of Physical Training, illustrated 111 ** No apparatus is required.

Sindow's Body Building, or Man in the making, how to become healthy and strong ... $1904 \ldots$

Breathing, for bealth, athletics and brain work, by Eustace Miles

Quickness, an how to increase it, by Eustace Miles .. 014

\section{Boxing -}

Boxing, by R. Allanson Winn, illustrated. "Isthmian"

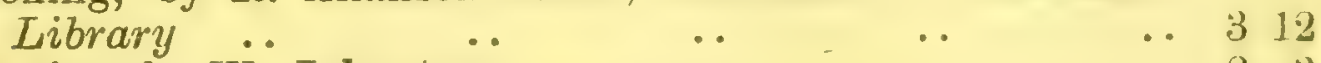
Boxing, by W. Johnstone ** Uniform with Sandow's Strength.

Boxing. "All England," Series .. $\quad$. $\quad \ldots \quad 012$ Wrestling, by Walter Armstrong. "All England" Series.. 0 12

\section{Higginbotham \& Co., Madras \& Bangalore.}




\section{Higginbotham \& $\mathrm{C}_{0}$., Madras \& Bangalore.}

\section{Riding -}

Hayes' Riding and Hunting, new and revised edition, including the substance of his "Riding on the Flat and Across Country," illustrated.. … .. 140 The Horsewoman, a practical guide to side-saddle riding, by Mrs. Hayes, edited by Capt. Hayes, new edition. fully illustrated

Eva Christy's Side-Saddle Riding .. Riding and Polo. Badminton. Librar!! The hands in Riding, by "Cesarexo"

$\begin{array}{rrrr}. & \ldots & 10 & 8 \\ . . & \ldots & 3 & 1 \\ \ldots & \ldots & 5 & 4 \\ . & 1905 \ldots & 4 & 6\end{array}$

\section{Golf-}

Golf, by H. E. Hutchinson and others. Lliustrated. Bad-

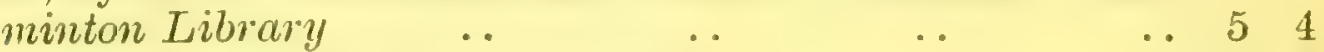

Golf and Golfers, past and present .. $\quad \ldots \quad \ldots \quad$. 12

Hints on Golf, by Horace Hutchinsoli $\quad$. $\quad \ldots 012$

Golf in Theory and Practice, some hints to beginners, by H.S.C. Everard, 22 illustrations. "All England" Series 18 The World of Golf, by G. G. Smith. "Isthmian" Library 312 Beldam's Great Golfers: their methods at a glance, with contributions by well-known Golfer's, illustrated by '268 Action Photographs _. $\quad$.. $\quad 1904 . .1015$

The Art of Putting, by IV. J. Travis. World's Champion, 1904, and Jack White, with Action Photographs, 1904 .. 140 


SMITHSONIAN INSTITUTION LIBRARIES 